\title{
Linking spawning ground extent to environmental factors - patterns and dispersal during the egg phase of four North Sea fishes.
}

\begin{tabular}{|c|c|}
\hline Journal: & Canadian Journal of Fisheries and Aquatic Sciences \\
\hline Manuscript ID & cjfas-2016-0310.R2 \\
\hline Manuscript Type: & Article \\
\hline Date Submitted by the Author: & 03-Feb-2017 \\
\hline Complete List of Authors: & $\begin{array}{l}\text { Höffle, Hannes; Queen's University Belfast, School of Biological Sciences } \\
\text { van Damme, Cindy; Wageningen IMARES } \\
\text { Fox, Clive; Scottish Association for Marine Science } \\
\text { Lelièvre, Stéphanie; Ifremer, Laboratoire Ressources Halieutiques } \\
\text { Loots, Christophe; Ifremer, Laboratoire Ressources Halieutiques } \\
\text { Nash, Richard; Institute for Marine Research, } \\
\text { Vaz, Sandrine; IFREMER, UMR MARBEC } \\
\text { Wright, Peter; Marine Scotland, } \\
\text { Munk, Peter; Technical University of Denmark, DTU Aqua, National } \\
\text { Institute of Aquatic Resources, Section of Oceanography and Climate }\end{array}$ \\
\hline $\begin{array}{l}\text { Please Select from this Special } \\
\text { Issues list if applicable: }\end{array}$ & 39th Larval Fish Conference \\
\hline Keyword: & $\begin{array}{l}\text { Spawning distribution, DISPERSAL < General, Seismic surveys, CLIMATE } \\
\text { CHANGE }<\text { General, Demersal fish }\end{array}$ \\
\hline
\end{tabular}


1 Running title: Fish egg distribution in the North Sea

2

3 Linking spawning ground extent to environmental factors - patterns and

4 dispersal during the egg phase of four North Sea fishes.

5

6 HANNES HÖFFLE ${ }^{1 *}$, CINDY J. G. VAN DAMME ${ }^{2}$, CLIVE FOX ${ }^{3}$, STÉPHANIE LELIÈVRE ${ }^{4}$,

7 CHRISTOPHE LOOTS ${ }^{4}$, RICHARD D. M. NASH ${ }^{5}$, SANDRINE VAZ ${ }^{6}$, PETER J. WRIGHT

8 AND PETER MUNK

$10{ }^{1}$ DTU Aqua, National Institute of Aquatic Resources, Technical University of Denmark,

11 Kavalergården 6, DK-2920 Charlottenlund, DENMARK

$12{ }^{2}$ IMARES, Institute for Marine Resources and Ecosystem Studies, Haringkade 1, 1976 CP,

13 IJmuiden, The Netherlands

$14{ }^{3}$ Scottish Association for Marine Science, Scottish Marine Institute, Oban, PA37 1QA, UK

$15{ }^{4}$ IFREMER, Laboratoire Ressources Halieutiques, 150 quai Gambetta, BP699, F-62321,

16 Boulogne sur Mer, France

$17{ }^{5}$ Institute of Marine Research and Hjort Centre for Marine Ecosystem Dynamics, PO Box

181870 Nordnes, 5817 Bergen, Norway.

$19{ }^{6}$ IFREMER, UMR MARBEC, Avenue Jean Monnet, CS 30171, F- 34203, Sète Cedex, France

$20 \quad{ }^{7}$ Marine Scotland Science, Marine Laboratory, 375 Victoria Road, Aberdeen, Scotland, AB11

$219 D B$

23 *Correspondence. Queen's University Belfast, School of Biological Sciences, Medical

24 Biology Centre, 97 Lisburn Road, Belfast BT9 7BL, Northern Ireland, Tel. +44 (0)289024

252464 , h.hoffle@,qub.ac.uk 


\section{Abstract}

27 Previous studies have shown that four commercially important demersal species, namely cod

28 (Gadus morhua), haddock (Melanogrammus aeglefinus), whiting (Merlangius merlangus)

29 and plaice (Pleuronectes platessa) spawn in distinct areas across the North Sea. Based on two

30 comprehensive ichthyoplankton surveys in 2004 and 2009, the present study uses

31 Generalized Additive Mixed Models (GAMMs) to delimit these spawning grounds using the

32 distribution of recently spawned eggs, investigates their relationship to specific

33 environmental conditions and examines egg dispersal during their development. Results

34 indicate that presence/absence of early stage eggs is more related to temporal and topographic

35 variables, while egg densities are closely linked with hydrography. Egg distribution patterns

36 were relatively consistent during development and only changed near hatching. Compared to

37 historic observations, the location of the spawning grounds appeared stable on the broad scale

38 but centres of egg abundance varied between the surveyed years. Potential effects of long-

39 term climate change and anthropogenic short-term disturbances, such as seismic surveys, on

40 fish reproduction are discussed, pointing out the demand for multi-species studies on these

41 issues.

42

43

44

45 Keywords: Spawning distribution, dispersal, seismic surveys, climate change, demersal fish 46 


\section{Introduction}

48 Annually visited spawning grounds are a common feature in the life cycle of many fish

49 populations (Daan et al. 1981; Heath et al. 1994), and have been demonstrated for a number

50 of commercially important fish species in the North Sea (e.g. Brander 1994; González-Irusta

51 and Wright 2016a; 2016b). Such stability in reproductive strategy is thought to have evolved

52 to ensure that, during the average lifetime enough offspring are placed into suitable

53 environments to ensure the population's survival. Suitable conditions for survival may be

54 found in the vicinity of the spawning ground or in nurseries with good connectivity to the

55 spawning grounds. Bakun (1996) coined the term 'ocean triads' for areas where zooplankton

56 is plentiful due to enrichment from nutrients, and where fish offspring are retained in a given

57 water mass. In the North Sea, such conditions could be found at tidal and salinity fronts

58 (Simpson et al. 1993). For fish spawning in late winter and spring salinity fronts may be more

59 important (Munk et al. 2002; Munk et al. 2009) as increased freshwater runoff during fall and

60 winter widens the region of freshwater influence (ROFI), particularly in the southern North

61 Sea (Simpson et al. 1991). Previous studies have suggested that the four commercially

62 important species cod (Gadus morhua), haddock (Melanogrammus aeglefinus), whiting

63 (Merlangius merlangus) and plaice (Pleuronectes platessa) all make use of recurrent

64 spawning grounds in the North Sea which may be linked to such hydrographic features.

65 In the southern North Sea cod spawns in relatively cool water $\left(5-7^{\circ} \mathrm{C}\right)$ beyond the 32

66 isohaline (Aurich 1941). North Sea cod appears to have four distinct spawning grounds, the

67 Southern and German Bights, the southern and eastern flanks of Dogger Bank and off

68 Flamborough (Aurich 1941; Lelièvre et al. 2010; Daan 1978). The recurrent use of the latter

69 area could, however, not be confirmed from findings of a more recent survey in 2004 (Fox et

70 al. 2008). Further north, ripe and running cod have been observed on the Great Fisher and

71 Ling Banks as well as in the coastal areas (<100 m depth) of Scotland (Graham 1934; 
72 González-Irusta and Wright 2016a). In the 2000s the main cod spawning grounds in the

73 northern North Sea were found off the north and east Scottish coasts and east of Shetland

74 towards Viking Bank (González-Irusta and Wright 2016a). Cod in the North Sea do not

75 appear to be a single stock as recent genetic evidence indicates that fish in the deeper

76 northern waters east of Shetland are genetically distinct from other North Sea populations

77 (Heath et al. 2014). In the northernmost North Sea, haddock spawning predominates in the

78 Atlantic influenced water of the deeper outer shelf, (González-Irusta and Wright 2016b;

79 Heath et al. 1994). Haddock rarely spawns in the southern North Sea, spawning has only been

80 extending as far south as the German Exclusive Economic Zone (EEZ) during a pulsed

81 recruitment (Aurich 1941). In the North Sea, haddock egg production appears highest outside

82 the Moray Firth and east of Orkney, though the eggs and larvae spawned to the west of

83 Scotland are advected into the North Sea (Heath and Gallego 1998) and the two regions are

84 treated as one stock for management purposes (ICES 2015).

85 North Sea whiting is divided into two genetically distinct northern and southern spawning

86 populations (Charrier et al. 2007). This species is among the most prolific spawners in the

87 North Sea, and it has both individually and collectively, an extended spawning period

88 (Aurich 1941). Compared to cod it appears to spawn in warmer water, having an optimum of

$895-8^{\circ} \mathrm{C}$, and eggs can be found in the southeastern inshore areas (Lelièvre et al. 2010). The

90 main centres for egg production of the southern population are on the western side, off

91 Flamborough, south of the Dogger Bank and in the Southern Bight, while the northern

92 population has its centre south of Shetland (Loots et al. 2011b).

93 North Sea plaice spawns in a large area of the southeastern North Sea, from the Southern

94 Bight northwards through the German Bight and along the coast of Jutland (Taylor et al.

95 2007). On the western side of the North Sea, plaice eggs have been found from Flamborough

96 up to the Moray Firth and further northeast off Shetland. The southwestern populations of 
97 plaice appear to spawn mainly in the Southern Bight and partially in the eastern English

98 Channel (Houghton and Harding 1976; Hunter et al. 2004). Generally plaice spawns further

99 offshore than most other flatfish species, with the main egg production observed $50-200 \mathrm{~km}$

100 offshore, in salinities $>32$ (Rijnsdorp 1989). Freshwater from the river plumes apparently has

101 a strong effect on spawning outside the core areas (Lelièvre et al. 2014). The location of the

102 spawning areas is thought to offer good connectivity to inshore, spatially limited, soft

103 sediment nursery grounds (Hufnagl et al. 2013).

104 Life-cycle closure requires a succession of suitable habitats and appropriate mechanisms for

105 transiting between them (Petitgas et al. 2013). There are concerns that predicted climate

106 change may not only affect reproduction directly but also affect early life stage habitats and

107 the connectivity between them (Collins et al. 2013). The changes would have a series of

108 direct and indirect effects, taking place on scales ranging from individuals to populations. It

109 has already been seen that North Sea fish distributions have responded to rising sea

110 temperatures (Perry et al. 2005) whilst changes in wind patterns and restricted transport of

111 Calanus finmarchicus into the North Sea have been implicated in cod recruitment (Rindorf

112 and Lewy 2006; Fromentin and Planque 1996). Under climate change the location of salinity

113 fronts, which may direct spawning, could also change (Collins et al. 2013; Perry et al. 2005).

114 Such changes may be especially detrimental for fish species on the southern edge of their

115 range, while other species may be able to extend into the North Sea (Dulvy et al. 2008;

116 Planque and Frédou 1999). Many North Sea stocks have also suffered decades of overfishing,

117 leading to low spawning stock biomasses (SSBs) and truncated age structures. Such stocks

118 may have reduced resilience against changes in the abiotic environment (Ottersen et al.

119 2006). Other human activities may put additional stress on spawners and their offspring,

120 particularly in a heavily industrialized area like the North Sea, containing nearly a thousand

121 active above- and sub-surface structures (De Groot 1996; OSPAR Commission 2014). Except 
122 for specific accidents these structures, may, however, only be local disturbances and may

123 even serve as habitat (Løkkeborg et al. 2002; Fujii 2015). Other disturbances might come

124 from seismic exploration which nowadays uses airguns that cause direct physical damage in a

125 much narrower zone than the explosives used in the past (5 m, McCauley et al. 2000). Effects

126 on adults may rather be indirect, causing avoidance of approaching survey vessels. Since

127 seismic surveys are not supposed to be undertaken during periods of fish spawning, or are

128 supposed to use mitigation measures such as soft-starts (Smithies 2014), knowledge of the

129 extent and timing of spawning is essential for proper Environmental Impact Assessment

130 (EIA). Therefore, evaluating the overlap between intense seismic operations and spawning

131 grounds is a normal requirement for EIAs undertaken before seismic operations commence.

132 In 2004 and 2009, dedicated surveys and additional sampling during routine surveys were

133 coordinated by ICES, affording the possibility to examine fish spawning using egg

134 distribution data separated by 5 years.

135 Here we use the egg distribution of the four most abundant species, cod, haddock, whiting

136 and plaice in order to (i) construct statistical models, relating the spawning habitat inferred

137 from stage I eggs, up to the onset of gastrulation, to the abiotic environment; (ii) examine

138 how distribution patterns changed over time by constructing interpolated distribution maps

139 and by statistically comparing the distribution of the successive egg development stages; (iii)

140 evaluate to which extent spawning distribution overlaps with industrial activities and how

141 these, in concert with climate change, may affect future spawning distribution and success. 


\section{Materials and methods}

\section{Survey design and field sampling}

144 Sampling was carried out across the North Sea (Fig. 1a) by five participating countries, either 145 during the annual International Bottom Trawl Survey for the first quarter (IBTS 1Q) or in 146 dedicated surveys between the $16^{\text {th }}$ February and $23^{\text {rd }}$ of March 2004 and between $17^{\text {th }}$ of 147 January and $6^{\text {th }}$ of March 2009 (Table 1).

148 The samples were taken with Gulf III/Nackthai (Gehringer 1962; Nellen and Hempel 1969),

149 Gulf VII (Nash et al. 1998), BONGO (Posgay and Marak 1980) and WP2 (Fraser 1968;

150 Tranter 1968) nets, covering the entire North Sea from $51.5^{\circ} \mathrm{N}$ to $62^{\circ} \mathrm{N}$. The Gulf and

151 BONGO nets were deployed in double oblique hauls, while the WP2 was deployed in vertical

152 hauls, in both cases down to five metres above sea bottom or a maximum of $100 \mathrm{~m}$ depth.

153 Double oblique hauls lasted at least 10 minutes with multiple hauls ensuring the minimum

154 deployment time in shallow water (ICES 2008). To determine cod-like eggs to species level,

155 single eggs without oil globules and diameters of 1.1-1.75 mm (Fox et al. 2008) or 0.97-

$1561.89 \mathrm{~mm}$ (Lelièvre et al. 2010) were fixed for later genetic analysis, either in $96 \%$ ethanol

157 (Fox et al. 2008) or in a pigment preserving Battaglia-solution containing buffered 0.864\%

158 formalin, BHA (butylated hydroxyanisole), EDTA (ethylenediaminetetraacetic acid) and

159 monopropylen glycol and ascorbic acid (Mastail and Battaglia 1978; Bigot 1979).

160 The locations of installations for oil extraction, seismic survey areas and the outlines of

161 exclusive economic zones were extracted from public online databases (Fig. 1b, OSPAR

162 Commission 2014; Ministerie van Economische Zaken 2015; Oljedirektoratet 2015). Depth

163 and shoreline data were downloaded from NOAA databases (NOAA (NGDC) 2016a; NOAA

164 (NGDC) 2016b).

165

166 


\section{Egg and larvae identification}

168 Subsamples of at least 100 eggs in the desired size range ( $>1.16 \mathrm{~mm}$, Russell 1976) were

169 staged (Ryland et al. 1975; Geffen and Nash 2012) and visually identified to the lowest

170 possible taxonomic level (Munk and Nielsen 2005; Russell 1976). Preserved cod-like eggs

171 were identified either with TaqMan probes (Fox et al. 2008) or cytochrome $b$ PCR-RFLP

172 (Lelièvre et al. 2010). Accuracy of TaqMan probes is $>98 \%$ for cod, haddock and whiting

173 (Taylor et al. 2002) while cytochrome $b$ PCR-RFLP confirmed 98\% of visual identifications

174 for late-stage cod eggs and $71 \%$ for late-stage whiting eggs (Lelièvre et al. 2010). The

175 identified gadoid eggs were assigned to each species according to the proportion obtained

176 from genetic analyses. For stations where this was not possible, the proportion in 2004 was

177 derived from a multinomial Generalized Additive Model (GAM) over the whole survey area

178 (Fox et al. 2008) and in 2009 from the average proportion for the other stations in the same

179 ICES square. Counts of fish eggs were raised by the fraction of the whole sample examined

180 and then converted to density (eggs $\mathrm{m}^{-2}$ ), by dividing by the sampled volume and multiplying

181 by the sampled depth.

\section{Geostatistics}

184 Hydrographic data were obtained from CTD hauls during the survey and augmented with

185 data from the ICES oceanographic database (ICES 2009). After pre-screening for erroneous

186 measurements, density anomalies $\sigma_{\mathrm{t}}\left(\mathrm{kg} \mathrm{m}^{-3}-1000\right)$ were calculated from temperature and

187 salinity according to UNESCO standards (Millero and Poisson 1981) using the R package

188 oce (Kelley 2013). To calculate the density gradient, an experimental variogram for $\sigma_{t}$ was

189 calculated in Surfer 10 (Golden Software 2011) and a linear theoretical variogram model

190 fitted to the experimental variogram, using least square regression. Using ordinary kriging,

191 the density anomaly was then interpolated onto a regular grid of $0.25^{\circ} \times 0.25^{\circ}$ and 
192 subsequently smoothed to half that grid resolution. From the interpolated horizontal density

193 anomaly the density gradient in $\mathrm{g} \mathrm{m}^{-3} \mathrm{n} \cdot \mathrm{mi}^{-1}$ was calculated using the formula (Golden

194 Software 1999):

195

$$
\|\vec{g}\|=\sqrt{\left(\frac{Z_{E}-Z_{W}}{2 \Delta x}\right)^{2}+\left(\frac{Z_{N}-Z_{S}}{2 \Delta y}\right)^{2}}
$$

197 Where $\vec{g}$ is the density gradient, $Z_{E}$ and $Z_{W}$ are adjacent grid points in East-West direction; $Z_{N}$

198 and $Z_{S}$ are adjacent grid points in North-South direction, $\Delta x$ and $\Delta y$ the distances in either

199 direction, respectively.

200 For visual representation, temperature and salinity were interpolated on a $1 \mathrm{n} . \mathrm{mi} . \times 1 \mathrm{n} . \mathrm{mi}$.

201 grid using the R package gstat (Pebesma 2004). Analogous to the procedure for $\sigma_{\mathrm{t}}$ an

202 experimental variogram was calculated and a Gaussian, exponential or spherical theoretical

203 variogram was fitted to the experimental variogram using least-square regression and eye-fit.

204 The chosen model was then used for the interpolation. Average temperature and salinity data

205 for the 2000s was also interpolated following the same procedure. However, the value plotted

206 here was the variation, to visually compare the distribution of stage I fish eggs with the

207 variation of hydrography.

208 Similarly, data for each egg development stage were split into presence/absence and log-

209 transformed non-zero abundance and then interpolated using an ordinary kriging procedure

210 on the default grid in gstat (Pebesma 2004). The values for abundance were then weighted

211 with the probability of occurrence on a cell-by-cell basis and the final maps created by

212 kriging onto the same 1 n.mi. $\times 1$ n.mi. grid that was used for hydrography. 
213 Statistical comparisons of egg density distributions between stage I and the later stages were

214 performed using the Syrjala test in the R package ecespa (de la Cruz 2008). The Syrjala test

215 computes a modified two-sample Cramér-von Mises test for a difference between the

216 cumulative distribution functions of two populations (Syrjala 1996). As the test is sensitive to

217 where the coordinate system has its origin, it is performed once for each of the four corners of

218 the hypothetical rectangle encompassing all sampling sites and then averaged. Although the

219 test is insensitive to sample size, each sample was transformed to \%o of the sum of the

220 respective stage before conducting the test.

221

222

\section{Modelling spatial autocorrelation}

Spatial autocorrelation and average patch size were modelled with Moran's eigenvector maps (MEMs) using the R package pcnm (Legendre et al. 2013). A truncated distance matrix was computed by converting all distances farther than the longest distance between immediate neighbours to four times that value (Borcard and Legendre 2002). Since there are no interactions in the population of fish eggs, only the MEMs with positive eigenvalues were retained. Before running a global test on all MEMs with positive eigenvalues the hellingertransformed abundances were detrended to remove any spatial trend. Individual Moran's Eigenvectors (MEVs) were selected by regression-based forward selection with the $\mathrm{R}$ package packfor (Blanchet et al. 2008; Dray et al. 2013) using p-value and adjusted $r^{2}$ as stopping criteria. Similar to Loots et al (2010a) the threshold p-value was set to a low 0.002 , to avoid building too complex spatial models. The spatial scale was then determined by first computing a Gaussian variogram for each MEM (Bellier et al. 2007). Then the selected MEMs' eigenvalues were plotted against these ranges and subdivided into sub-models for a fine, medium, medium-broad and broad scale. 


\section{Explanatory models}

239 To examine the relationships between the distributions of stage I eggs and the abiotic

240 environment, data from both years were used to construct a generalized additive mixed model

241 (GAMM) with the R package gamm4 (Wood and Scheipl 2014; Wood 2006). As for the

242 kriged distribution maps, separate models were constructed for presence/absence and non-

243 zero abundance, resulting in a hurdle-model. Potential independent variables were temporal

244 (year, day of the year), bathygraphic (bottom depth), hydrographic (temperature, salinity, and

$245 \sigma_{\mathrm{t}}$-gradient; from the surface and bottom) and the selected MEVs. These variables were

246 examined for collinearity with pair plots and variance inflation factors (AED, Zuur 2010),

247 entailing the exclusion of the year. Hydrographic values were taken from the CTD casts taken

248 at the locations of the individual samples or, if not available or erroneous, were extracted

249 from the interpolated surfaces. The measurements from $5 \mathrm{~m}$ depth and the bottom were

250 strongly correlated. Instead of excluding one or the other, separate models using either

251 surface or bottom measurements were constructed and compared. MEVs were treated as

252 random effects, while the day of the year (=year day), bottom depth and the hydrographic

253 covariates were the fixed-effects. Using either presence/absence in a binomial model with a

254 logit-link or log-transformed non-zero egg densities in a Gaussian model with identity-link as

255 response, the general form of the GAMM was (Wood 2006; Höffle et al. 2014):

256

$$
y_{i}=\beta+f_{1}\left(x_{1 i}\right)+f_{2}\left(x_{2 i}\right)+\cdots+f_{n}\left(x_{1 n i}\right)+Z_{i} b+\varepsilon_{i}
$$

$258 y_{i}$ being the response, $\beta$ the intercept, $f_{i}$ the smooth functions for the fixed effects $x_{k}, b$ a

259 random effects coefficient vector from the matrix $Z_{i}$ and the residual error vector $\varepsilon_{i}$. 
260 The risk of over-fitting the individual models was reduced by restricting the degrees of

261 freedom to four and by using the Bayesian Information Criterion (BIC, Schwarz 1978) as an

262 indicator of improvement during the backward selection of the optimal models. Initial models

263 contained hydrographic measurements from either the surface $(5 \mathrm{~m})$ or the bottom depth.

264 Following the optimization of these models the decisions between either surface or bottom

265 models were based on BIC, Akaike's Information Criterion (AIC, Akaike 1974) and in case

266 of disagreement between the two on the predictive power of the models. Formal assessment

267 of the goodness of fit, since not possible from the GAMM itself (Wood 2006; Zuur et al.

268 2009), was done by estimating the deviance explained from a generalized additive model

269 (GAM) using the same fixed-effects covariates (Gilman et al. 2012). Post-hoc testing

270 included an evaluation of the random effects' contribution, using the residuals from the GAM

271 as response (Wood 2006). Hereby, linear fixed-effects and mixed models are compared, by

272 using a constant parameter and in the mixed model the random effects. The two models are

273 then compared by AIC, BIC and the log-likelihood ratio test.

274 The effect of the random covariates on the spatial autocorrelation was evaluated by Moran's I

275 correlograms on the models' residuals, setting a separation distance of $0.7^{\circ}$ for non-zero egg

276 densities of cod and plaice, $2.1^{\circ}$ for all other models, corresponding to the maximum distance

277 between nearest neighbours (Diniz-Filho et al. 2003; Borcard et al. 2011). The number of

278 lags to cover the entire study area was then 15 and 5, respectively. $P$-values were adjusted

279 using Holm's correction (Borcard et al. 2011).

280 The performance of individual fixed covariates was evaluated using three different indicators.

281 Firstly, by dropping each covariate individually and then calculating the log-likelihood ratio

282 between the reduced model and the model selected in the fitting process. Secondly, by

283 computing the ROC AUC (Receiver Operating Characteristic Area Under the Curve) for

284 binomial and the $r^{2}$ between response values predicted from individual covariates and the 
285 observations for Gaussian models using the R package MuMIn (Barton 2013). Lastly, partial

286 linear regression and adjusted $r^{2}$ were used to partition the explained variation explained by

287 the individual covariates using the R package vegan (Oksanen et al. 2013; Peres-Neto et al. 288 2006).

289

$290 \quad$ Results

\section{Hydrography}

292 In both years hydrography was characterized by a pool of relatively warm $\left(>7^{\circ} \mathrm{C}\right)$ and saline 293 (>34.5) water in the northern and central North Sea and cooler, fresher water along the 294 margins, which was more pronounced in the East (Fig. 2). Salinity (Figs 2b, d) as well as 295 density gradients (max. $4.3 \mathrm{~g} \mathrm{~m}^{-3} \mathrm{n} . \mathrm{mi}^{-1}{ }^{-1}$ off Norway) were steeper on the eastern side of the

296 North Sea. Surface hydrography was more structured than at the bottom. The main difference 297 between 2004 (Fig. S1) and 2009 (Fig. S2) was that in the southern North Sea water $\leq 6^{\circ} \mathrm{C}$ 298 extended further westwards in 2009. The water in the German Bight was more than $1^{\circ} \mathrm{C}$ 299 colder than in 2004 and salinity gradients from coastal to offshore waters were shallower, 300 particularly north of the Frisian Islands where a prominent plume of relatively fresh $(\leq 34.25)$ water extended far offshore. North of $57^{\circ} \mathrm{N}$ the situation was the opposite with the salinity gradient steeper in 2009 (Fig. S2) than 2004 (Fig. S1).

\section{Spatial structuring}

305 The threshold for truncating the distance matrix was $2^{\circ}$. Of the MEMs, 355 were found to

306 have positive eigenvalues. Two of these were significant for cod, four each for haddock and

307 plaice and one for whiting. When plotting eigenvalues against the variogram range, there

308 were four distinct groups (Fig. 3), on ranges of 0-40 n.mi. (fine), 40-75 n.mi. (medium), 75-

309100 n.mi. (medium-broad) and above 100 n.mi. (broad). 


\section{$311 \quad$ Egg distribution}

312 Stage I egg densities on the scale of the entire North Sea were in both years in the same

313 general areas (Fig. 4). High egg densities of cod (Fig. 4a) and plaice (Fig. 4p) were found in

314 the Southeast, along the continental coast, extending as far north as Viking Bank. Whiting

315 and haddock were more common in the western part. The centre of egg densities for haddock

316 was limited to the Northwest (Fig. 4f), two patches on either side of the Fladen Ground and a

317 third, smaller, patch outside the Firth of Forth. Peak densities of whiting eggs also occurred in

318 three locations but they were farther apart. One centre of abundance was east of the Shetland

319 Isles (Fig. 4k) around the Forties, the second, larger, area was between Flamborough and the

320 Dogger Bank and a third area was in the Southern Bight.

321 The overall pattern in the development over time was one of decline and dispersal. For cod

322 and whiting (Figs 4a-e, 4k-o) this process appeared to be quicker compared with haddock and

323 plaice with a sharp drop in egg densities between stages I and II and a lower rate of decline

324 thereafter. For haddock and plaice the peak densities did not decline as quickly (Figs 4f-j, 4p-

$325 \mathrm{t}$ ), densities of the same magnitude as in stage I were still observed in stages IV and V (Figs

$3264 \mathrm{i}, 4 \mathrm{t}$ ). However, the area covered by high densities shrank and in the case of haddock

327 divided into several smaller well-separated patches.

328 The main differences between the years (Figs S3, S4) were that the centres of abundance for

329 cod and plaice were further north and offshore in 2004 than in 2009 and that the rate of

330 dispersal differed between the years for each individual species. In 2004 high cod and plaice

331 densities covered a larger area (Figs S3a-e, S3p-t), from the transition area between the

332 Bights up to the southern edge of the Norwegian trench. For cod in 2009 this area was

333 smaller, more inshore, off the Frisian Islands, while egg densities were higher in the northern

334 patch around Viking Bank (Fig. S4a-e). For plaice the overall location was similarly changed, 
335 extending along an east-west axis rather than a north-south axis, but the extent of the area

336 was similar to 2004. Peak densities of cod eggs and the area covered with such densities,

337 quickly declined in 2009, while in 2004 high densities were still found in stage III (Fig. S3c).

338 There was no such difference for plaice, although in later stages (Figs S3s and S3t) the

339 location of peak densities was similar to 2009. High egg densities of haddock covered much

340 larger areas in 2004 (Figs S3f-j) than in 2009 (Figs S4f-j) and the distribution pattern did not

341 disperse as quickly and completely. Whiting egg densities were generally lower in 2009 than

342 in 2004 (Fig. S4k-o) but there was little difference in how quickly the eggs dispersed.

343 However, the overall pattern was different (Fig. S3k-o) with high densities in the Southern

344 Bight in 2009 while in the earlier year the centres of abundance were off Flamborough and 345 east of Shetland.

346 The Syrjala-test did not fully confirm the patterns suggested by the interpolated maps (Table

347 2). The distribution patterns of stage IV and $V$ were more often dissimilar from stage I than

348 those of earlier stages, but that pattern was not consistent across species or years. Although

349 stage IV was significantly dissimilar for all species when comparing mean distributions, it

350 never was for whiting in any of the single years. Similarly, the distribution of stage V was

351 significantly different for all species in 2004, but not in 2009 or for mean distributions. Stage

352 III never exhibited significant dissimilarity to stage I, although there were three cases of

353 significantly different distributions between stages I and II.

\section{Explanatory models}

356 The overall trends in the explanatory models were twofold. Firstly, the best fitting models for

357 non-zero egg density tended to be more complex than those for the probability of occurrence

358 (Table 3, Figs 5, 6). Secondly, although the difference was marginal, three out of four models

359 exhibited a better fit when using hydrographic measurements at the bottom for the probability 
360 of occurrence, while for egg densities it was the opposite. Deviations explained by the

361 corresponding GAMs ranged between 15\% for the density of stage I cod eggs and 57\% for

362 the presence/absence of haddock eggs. The models for these two species also consistently

363 retained the least fixed-effects covariates (3) for both cod models and the most (5) for both

364 haddock models (Table 3).

365 Bottom depth and year day were the only fixed-effects covariates retained in every model.

366 They also exhibited similarly shaped relationships for three of the four species (Figs 5a, b).

367 Cod, Haddock and Whiting exhibited an increasing trend towards the end of the period.

368 Plaice differed from the other species, exhibiting a dome shaped relationship between days 30

369 and 70. The relationships of cod and plaice egg densities with the year day were of similar

370 shape and peaked earlier than their probabilities of occurrence (days 45 and 35; Fig. 6a).

371 Whiting egg densities exhibited an early and a late peak around days 20 and 80, respectively.

372 Haddock egg densities were linearly and positively related to the year day.

373 Probabilities of occurrence for cod and plaice exhibited overall decreasing trends of similar

374 shape with peak probabilities at ca. $50 \mathrm{~m}$ (Fig. 5b). Haddock exhibited a similar pattern, but

375 shifted towards greater depths, with a peak at around $100 \mathrm{~m}$ and an increasing trend towards

376 the end of the observed depth range. The probability of finding stage I eggs of whiting

377 declined with increasing depth, becoming zero at $\geq 150 \mathrm{~m}$ (Fig. 5b). Relationships between

378 egg densities and bottom depth were of similar shape for cod, whiting and plaice, with peaks

379 at shallower depth than peak probabilities of occurrence (Fig. 6b). Haddock egg densities

380 exhibited a Gaussian distribution around $100 \mathrm{~m}$.

381 Other than for time and depth, the relationships between the probability of presence and the

382 hydrographic covariates were more species specific with no consistent patterns between any

383 two species. Temperature did not contribute to the model for the occurrence of cod eggs and

384 exhibited negative and positive trends for plaice and whiting, respectively (Fig. 5c). For 
385 haddock the probability of finding eggs was high across the temperature range, except for a

386 local decline around $6^{\circ} \mathrm{C}$. Unlike for probability of occurrence, the smooth terms for egg

387 densities related to hydrographic measurements exhibited similarities between two or more

388 species. Haddock consistently differed from the other species, exhibiting linear or near-linear

389 increases in egg densities in relation to year day, salinity and density gradient. Temperature

390 contributed to all models for egg density with the peak occurring as low as ca. $5^{\circ} \mathrm{C}$ for plaice

391 and as high as $9^{\circ} \mathrm{C}$ for whiting. The smooth terms for cod and plaice were similar in shape

392 and both egg densities peaked at nearly the same temperatures. Observations at either end of

393 the observed temperature range were few and therefore have wide confidence intervals.

394 Salinity contributed to the model for the probability of occurrence of cod eggs (Fig. 5d) but

395 did not contribute to the model for egg densities (Fig. 6d). Cod probability of occurrence

396 exhibited a weakly declining trend towards higher surface salinities, while haddock was

397 strongly positive related to bottom salinity. Salinity was only retained in the models for egg

398 densities of whiting and plaice, exhibiting similar shapes of the smooth terms, with peaks at

399 the lower end of the range and at salinities of 34. Haddock eggs were only observed in a

400 narrow salinity range and the trends of probability of occurrence as well as egg densities were

401 strongly positive. The density gradient was retained in the presence/absence models for

402 haddock and whiting (Fig. 5e) and the egg density models for these two species as well as for

403 plaice (Fig. 6e). Egg densities of all three species were linearly related to density gradients.

404 Across all species the relationships to the MEVs describing spatial autocorrelation were

405 linear or dome shaped (Figs S5 - S8). Spatial autocorrelation in the residuals was by a factor

406 of 1.5 to 7.5 lower than in the data used for fitting. However, on the first lag it remained

407 significant (Table 3).

408 Predictive power of the selected models was highest for the presence/absence of haddock, the

409 egg density model of whiting and lowest for both models for cod (Table 4). Individual 
410 covariates with high predictive power strongly affected the log-likelihood ratios as well

411 (Table 5). Concerning explained variation this consistency in performance of individual

412 covariates was limited to cod (Table 6). The variation explained by the fixed-effects

413 covariates was lowest for cod and highest for haddock. The highest percentage of explained

414 variation in presence/absence was related to bottom depth for plaice and year day for all other

415 species. For the egg densities the highest percentage of explained variation was related to

416 temperature for cod, salinity for haddock, and density gradient for whiting and plaice,

417 respectively. This increased importance of hydrographic variables in the egg density models

418 was not reflected in the predictive power or the log-likelihood ratios where these covariates

419 were usually weaker than either year day or bottom depth.

420 The comparison between the GAMMs and their corresponding GAMs using only the fixed-

421 effects covariates revealed that the MEVs only contributed significantly to the models for

422 whiting (Table 7). However, even for whiting the GAM was more parsimonious, as the AIC

423 and BIC was for all GAMs lower.

425 Comparison with decadal hydrography and oil installations

426 Averaged over the 2000s the variation in bottom temperature exhibited a range of interannual

427 variability between $<1{ }^{\circ} \mathrm{C}$ and $>1.6^{\circ} \mathrm{C}$ (Fig. 7a). The lower part of this range was found in

428 large areas of the central and southern North Sea, while the rest of the North Sea proper

429 exhibited intermediate variation. High variability was primarily indicated on the northern

430 margins of the North Sea and between the Shetland and Orkney Isles as far south as the

431 Moray Firth. High egg densities across all four species were primarily found at the

432 boundaries between the areas of low, intermediate and high variability. The mean density of

433 stage I eggs across all species, compared to the distribution of oil extraction and seismic

434 survey areas in the eastern North Sea showed that at this time of the year areas of high egg 
435 densities primarily overlapped with the oil industry in the southeastern North Sea in the

436 Dutch and German EEZs (Fig. 7b).

437

438 Discussion

439 The results of the present study indicate that presence/absence and non-zero abundance of 440 cod, haddock, whiting and plaice eggs are primarily governed by different environmental 441 variables. Presence/absence was mainly linked with the day of the year as well as bottom 442 depth whilst non-zero abundance was linked to one or more of the hydrographic covariates.

443 Overall, the spawning of cod and plaice appears more common in the southeastern North Sea, 444 while spawning of haddock and whiting were concentrated in the western areas, and in the 445 case of haddock further limited to the northern North Sea. The overall spawning areas seem 446 to have remained stable, compared to historical observations. However, the, smaller, actual 447 spawning grounds used within those areas varied between the two years surveyed depending 448 on prevailing conditions.

\section{$450 \quad$ Egg distribution}

451 Where spawning locations persist over many years their use must allow sufficient offspring 452 to survive to sustain the population size (see Hufnagl et al. 2013). Our observations of 453 geographically relatively stable spawning areas contrast findings for other species such as, 454 e.g. mackerel (Scomber scombrus, Beare and Reid 2002). However, even for mackerel the 455 spawning occurs mainly along the shelf-break and this location may be linked to patterns in 456 secondary production driven by internal waves (Sharples et al. 2009). Areas of the North Sea

457 where high abundances of cod, haddock, whiting and plaice eggs were found are consistent 458 with earlier studies (Coull et al. 1998; Heath et al. 1994). However, their extent at higher 459 population levels might be greater and at the present time the maximal extent of the spawning 
460 areas may be better indicated by egg occurrence (Brander 1994). The overall better fit for the

461 presence/absence models when including hydrographic measurements from the bottom rather

462 than from the surface may be due to the generally demersal behaviour of the adult fish. On

463 the other hand the better fits for egg densities using surface hydrography may be based in the

464 distribution of pelagic eggs in the upper part of the water column (Coombs et al. 1990;

465 Fritsch 2005). After rising to the surface layer, eggs will be advected from the spawning site.

466 However, in the observed temperature range the eggs develop to the end of stage I within a

467 few days (Thompson and Riley 1981; Geffen and Nash 2012). At common winter current

468 velocities (Sündermann and Pohlmann 2011), dispersal during that time should have been on

469 about the same scale as the survey. This is supported by recent studies on the distribution of

470 mature adults which largely corroborate the finding from the egg surveys (González-Irusta

471 and Wright 2016a; González-Irusta and Wright 2016b; Loots et al. 2011b) The only major

472 difference was that the northern core spawning grounds of whiting extended further south

473 than was observed in the egg surveys (Loots et al. 2011b). Therefore, the distribution of stage

474 I eggs observed in 2004 and 2009 may be considered a reliable source of information on

475 spawning distribution.

476

477 Relationship with the abiotic environment

478 Compared to Otto and Zimmermann (1990) and the studies underlying that review (Goedecke

479 et al. 1967; Tomczak and Goedecke 1962), the overall pattern of hydrography in the North

480 Sea in 2004 and 2009 was not much changed since the 1960s. Patterns were also similar

481 between the sampled years with the main differences in temperature and salinity occurring

482 south of $57^{\circ} \mathrm{N}$. A major difference between the two survey years were the higher egg

483 densities of whiting in the Southern Bight in 2009. The difference in egg densities in the

484 Southern Bight correlates with the hydrographic differences, as whiting may have spawned 
485

486

487

488

489

490

491

492

493

494

495

496

497

498

499

500

501

502

503

504

505

506

507

508

509

across the boundary between the cool, low salinity coastal water and the warmer water from

the South, corresponding to the species preferences (Aurich 1941). In the southern North Sea

a comparable data set is available from a series of surveys using the Continuous Underway

Fish Egg Sampler (CUFES, Lelièvre 2010). In this study high egg densities of all species

were found in the Southern Bight in 2006 and 2008, but to a lesser extent in 2007 (Lelièvre et

al. 2012). In 2006 low salinity was not restricted to the German Bight and the interface

between fresh and saline water was further offshore, resembling the situation in 2009. From

the comparison of the years we deduce that a more seaward position of the boundary between

freshwater influenced areas and marine water may attract more spawning fish to the area.

The present observations on cod egg distribution are consistent with Aurich (1941) and

Brander (1994). The latter author identified the western-central North Sea $\left(2^{\circ} \mathrm{W}-2^{\circ} \mathrm{E}\right.$ and

$52.3-56^{\circ} \mathrm{N}$ ) as a minor contributor to the spawning of cod, and the German and Southern

Bights as major contributors in alternating periods, 1948-1956 and 1958-1972, respectively.

In 2004 and 2009, the distribution of cod eggs in the Southern Bight was limited to a few

patches, while in the German Bight cod eggs were widespread, similar to the pattern described by Brander (1994).

Densities of cod eggs peaked in areas shallower than $100 \mathrm{~m}$, corresponding to results of previous ichthyoplankton studies (Munk et al. 2002) and in line with González-Irusta and Wright (2016a) who reported that the abundance of cod in spawning condition declined at more than $125 \mathrm{~m}$ water depth (González-Irusta and Wright 2016a). The temperature (ca. $4^{\circ} \mathrm{C}$ ) at these locations corresponded to the distribution of spawners which declined when temperatures increased to above $5^{\circ} \mathrm{C}$ (González-Irusta and Wright 2016a). Cod larvae tend to aggregate at or slightly inshore of a frontal system (Munk et al. 1999) but for the presence/absence and abundance of cod eggs the gradient in water density did not appear to be an important covariate in our analyses. Hence, the aggregation around fronts may only 
510 become established by selective processes or behaviours taking place in the larval stage.

511 Patterns of egg production were not entirely consistent with predictions based on the catches

512 of mature female cod in research surveys (Fox et al., 2008). This was particularly the case in

513 the northern North Sea where the bulk of the cod stock is presently located and where high

514 egg production would be expected. Cod in the northern population centred around Viking

515 Bank spawn several weeks later than those in the southern North Sea (González-Irusta and

516 Wright 2016a), which may call for changes in the timing of future ichthyoplankton surveys.

517 The greatest spawning concentrations of haddock have historically been reported from the

518 plateau between the Orkney-Shetland Isles and Norway in water deeper than $100 \mathrm{~m}$

519 (Thompson 1928). A statistical model developed for spawning haddock west of Scotland also

520 indicated a decline at greater depths, which corroborates the egg-based model in the present

521 study (González-Irusta and Wright 2016b). Spawning aggregations have also been reported

522 east of the Moray Firth, at the Buchan and Farne deeps, the Gut and the Fisher Banks. Saville

523 (1959) found haddock eggs to be widely distributed across the northern North Sea from the

524 Scottish coast to the Norwegian deeps except for the Moray Firth and an area around the

525 Fladen Ground. The low egg densities around the Fladen Ground appear a consistent feature,

526 as they were also noted by Damas (1909), González-Irusta and Wright (2016b) and in the

527 present study. The extent of haddock eggs found by Heath et al (1994) in 1992 was

528 comparable with that of Saville's study, although eggs were concentrated further north and

529 west. Heath and Gallego's (1998) study estimated high egg production from mature fish for

530 the Moray Firth, the Scottish east coast and Shetland Isles, which is reflected in the results of

531 the two surveys. However, their model did not predict high abundances to the immediate east

532 of the Shetland Isles, which were present in 2004, 2009 and earlier egg surveys. High

533 abundances of haddock eggs south of the Moray Firth were only found in 2004. In earlier

534 plankton surveys Heath et al. (1994) found a spatial segregation of late stage cod and 
535 haddock eggs, in colder North Sea water and on the warmer outer shelf, respectively. These

536 findings support the suggested preferences for different zones of a frontal system between

537 these gadoids (Munk et al. 1999). More common occurrence and higher abundance of

538 haddock eggs on the offshore side of a frontal system, was also seen in the relationships to

539 the environmental covariates. Observations of haddock eggs were limited to a narrow part of

540 the species' salinity range (30-36, Laurence and Rogers 1976). Within the observed range,

541 the probability of occurrence as well as egg densities increased. Likewise the warmer

542 offshore water, where a local peak was found at $7^{\circ} \mathrm{C}$ in the present study, falls within the

543 species' temperature range $\left(4-10^{\circ} \mathrm{C}\right.$, Laurence and Rogers 1976). Similarly, spawning

544 haddock reached peak probability of presence and abundance at $7^{\circ} \mathrm{C}$ and exhibited peaks at

545 salinities $>34$ and $>35$, respectively (González-Irusta and Wright 2016b). Density gradients in

546 the northern North Sea were lower than in the South. Nevertheless, they positively affected

547 the abundance and to a lesser extent the occurrence of haddock eggs. This may be related to

548 the observed high numbers of eggs on the oceanic side of the front between the Atlantic and

549 the North Sea water in the northwestern North Sea (Heath et al. 1994).

550 It has been suggested that the whiting population consist of two stocks in the North Sea, one 551 east of England and one east of the Shetland Isles (Charrier et al. 2007). Such separation is

552 consistent with our findings. The preferred habitat of adult whiting can be characterized by

553 shallow depths and relatively high winter temperatures of $6-9^{\circ} \mathrm{C}$ (Damas 1909). This

554 preference was apparently reflected in the higher probability to find whiting eggs as well as

555 higher egg densities in the upper temperature range. Egg abundance peaked not only at

556 temperatures $>7^{\circ} \mathrm{C}$ but also at sub-optimal temperatures of $4^{\circ} \mathrm{C}$, but still within the thermal

557 range for egg survival (Povoa et al. 2011). Probability of occurrence and abundance peaked

558 in the 20-40 m range identified as preferred depth range for spawning by Aurich (1941). The

559 likelihood to find whiting eggs increased at high density gradients, while the egg densities 
560 declined, partially corroborating the findings of Munk et al (1999), who found that whiting

561 eggs were uncommon at central parts of fronts. Whiting has a long spawning period, from

562 February to June with increasingly later spawning at higher latitudes (Hislop 1984). Hence,

563 the earlier sampling period in 2009 may partially explain the difference to 2004, particularly

564 in the northern spawning grounds east off Shetland. In 2009 spawning east of Shetland may

565 not have begun at the time of the survey. However, in 2004 stage IV and V eggs were

566 abundant in the North, while early stages occurred more in the southern North Sea, contrary

567 to the observations by Hislop (1984) and Aurich (1941). As individual whiting spawn many

568 batches over a period between 1.5 and 2 months into late spring (Hislop 1984), the 2004

569 survey may have sampled the early stages of a later spawning batch in the South, while in the

570 North the previous batch was sampled in the later stages.

571 The relatively homogenous distribution of plaice eggs in the German Bight and along the

572 Danish coast, particularly in 2004, is a good representation of this species' large spawning

573 area in the southern North Sea and English Channel (Aurich 1941; Metcalfe 2006). Moray

574 Firth, Firth of Forth and the area off Flamborough Head are further suitable for plaice

575 spawning (Loots et al. 2010b) and some eggs were found there, in earlier surveys (Aurich

576 1941) and in the present study. To develop successfully, plaice eggs need a temperature range

577 of $2-8^{\circ} \mathrm{C}$ (Wegner et al. 2003), which was reflected in the above average abundance of eggs

578 at $4-6^{\circ} \mathrm{C}$. The probability of finding plaice eggs was similarly highest at the lowest observed

579 temperatures and declined linearly over the observed range, indicating that within the

580 species' thermal range the lower part is preferred (Wegner et al. 2003). The high densities of

581 plaice eggs at salinities $\geq 34$ corroborated earlier studies indicating high salinities as optimal

582 for plaice eggs (Aurich 1941; Cushing 1990). The linear relationship between egg densities

583 and density gradient was negative and had a similar slope to that for whiting. This result 
584 supports earlier studies indicating more offshore spawning grounds than other flatfish

585 (Lelièvre et al. 2014).

586 Overall, egg densities declined quickly between stages I and II and at a lesser rate towards

587 later development stages. However, distribution patterns remained largely the same up to

588 stage IV. Therefore, one can assume that the decline was primarily driven by the high

589 mortality of fish eggs (Bunn et al. 2000), and that mortality rates were similar across the

590 North Sea. Contrary, dispersal may be rather slow. In the southern North Sea, eggs are

591 advected at about $5 \mathrm{~km} \mathrm{~d}^{-1}$ (Brander 1994), resulting in a transport of around a $100 \mathrm{~km}$ from

592 spawning to hatching, based on temperature dependent egg development (Thompson and

593 Riley 1981; Geffen et al. 2006). This slow dispersal may explain why distribution patterns

594 remained similar until the later stages. As indicated by $p$-values in the Syrjala-test,

595 distribution patterns of stages I and III were often more similar than those of stage I and II.

596 This may be due to the difference in duration of development stages. It is less likely to find

597 stage II eggs during a survey, as it is comparatively short (Fox et al. 2003; Geffen et al.

598 2006).

599 Areas with high densities of haddock eggs, similar to densities in stage I, were maintained

600 longer than for cod and whiting. Partially this might be due to a larger contiguous area with

601 high densities to start with. Another factor may be that the distribution of adult haddock in

602 the first quarter changes little (Hedger et al. 2004), suggesting that predators were satiated by

603 a continuous supply of freshly spawned eggs rather than feeding on the less numerous later

604 stages. A similar mechanism may be at work in case of plaice, which also started out with a

605 large area of high densities that shrank but did not disappear over time.

606

607

608 


\section{Individual covariates}

610 The greater importance of the hydrographic variables concerning explained variation, and to

611 a lesser extent predictive power and the log-likelihood ratios, in the egg density models

612 contrasts with the findings of earlier studies. In the present study the year day was the most

613 influential covariate in determining presence/absence. However, earlier studies indicated that

614 environmental covariates are more important for defining the boundaries of a population's

615 habitat, rather than the distribution within (Loots et al. 2011a; Loots et al. 2010a). However,

616 it is not without precedent. Although they used a different measure, Gonzáles-Irusta and

617 Wright (2016a) came to a similar result for the abundance of North Sea cod in spawning

618 condition. In their study, temporal covariates were likewise the most important ones,

619 followed by salinity as the most important hydrographic covariate. Still, the importance of the

620 year day must be interpreted with care, due to the time series being short and the survey

621 periods differing by about three weeks. Longer time series with several samples on the same

622 year day may reduce its influence (e.g. Höffle et al. 2014; Lelièvre et al. 2014). The

623 distribution of populations on the edge of their environmental range may experience a

624 stronger influence of the environment, which may apply to cod and haddock. Haddock is

625 environmentally restricted to the northern North Sea and while distributed across the North

626 Sea, cod still experiences a strong influence of temperature, because the North Sea stock is

627 one of the most southernmost ones (Hedger et al. 2004; Drinkwater 2005).

628 MEMs are a powerful tool to deal with spatial autocorrelation. However, the additional

629 covariates may be penalized in model selection (Loots et al. 2011a). This may be one reason

630 why only the models for whiting exhibited a significant difference in the log-likelihood ratio

631 test, as they only contained a single MEV on the broad scale. Broad scale structures were also

632 those with the most discernible patters when plotting observations against predictions, 
633 indicating that these structures were likely more important for characterising the spatial 634 distribution of spawning than those on smaller scales.

635

636 Long-term change and short-term disturbances

637 The four species in the present study may be affected in different ways by long-term changes

638 in environmental conditions of the North Sea, potentially compounded by short-term

639 disturbances (Collins et al. 2013; Petitgas et al. 2013). The debate whether recent changes in

640 the distribution of some North Sea species are related to climate change or to changes in local

641 populations is still ongoing (Neat and Righton 2007; Holmes et al. 2014). The present study

642 indicates that effects would be species specific, with cod and haddock experiencing stronger

643 direct effects of rising temperatures (Hedger et al. 2004; Drinkwater 2005). However,

644 Petitgas et al. (2013) highlighted the potential impact of indirect effects on species with

645 specific habitat requirements for spawning grounds or nurseries as well as on the connectivity

646 between these areas. Plaice appears to be particularly vulnerable as spawning grounds are

647 offshore and the, narrowly defined, nursery areas inshore (Hufnagl et al. 2013). North Sea

648 plaice is one of the more southern populations and suitable spawning grounds and nurseries

649 may decrease in size (Petitgas et al. 2013). Connectivity may be affected by accelerated

650 development and changing current patterns through changes in wind and runoff patterns. For

651 the period 1975 to 2006 Hufnagl et al. (2013) observed a decrease in connectivity related to

652 an increase in temperature, for the spawning grounds in the German Bight and in the English

653 Channel, while connectivity for other areas increased. For cod, connectivity may be affected

654 in the opposite way, as climate change may entail more natal retention (Heath et al. 2008).

655 However, other studies suggested a displacement to the North (Rindorf and Lewy 2006).

656 Whiting may also be affected by changes in salinity and subsequently stronger density

657 gradients in its, previously more homogenous, spawning areas (Loots et al. 2011a). 
658 While the effects of changes in climate are long-term, short-term disturbances may interact

659 with them. Noise producing activities, such as seismic surveys as well as construction work

660 and the ensuing avoidance reactions, may lead to delays in spawning or avoidance of optimal

661 spawning grounds and therefore interfere with successful connectivity between spawning and

662 nursery areas. Together with minor injuries and their effects on long-term survival such

663 indirect effects of noise pollution are understudied and call for further research (Wahlberg

664 and Westerberg 2005; Payne 2004). Such impacts are considered in the EIA that must be

665 undertaken before seismic surveys are conducted. Where potential impacts are judged serious

666 then mitigation measures must be taken. Mitigation can include restricting the timing of work

667 so it is outside of the spawning season or other measures such as soft-starts for pile-driving

668 and air gun surveys. It is therefore important that up-to-date information is available

669 regarding spawning locations and timing so that offshore exploration and construction

670 activities can be properly controlled. Of the four species in the present study, cod and plaice

671 overlap with areas for seismic surveys, whether for oil exploration or construction work, in

672 the southeastern North Sea (Ministerie van Economische Zaken 2015). Cod may be

673 vulnerable due to its SSB being below $B_{\text {trigger, }}$ the biomass triggering management actions,

674 while plaice is vulnerable due to its dependence on successful connectivity between early life 675 stages.

\section{Conclusion}

678 Spawning areas appear to be defined by few, time-invariant variables, while centres of

679 abundance within these areas are influenced by the interannual variability of the hydrographic

680 conditions. Explanatory power of the statistical models varied between 15\% explained

681 deviation for cod egg density and 57\% for haddock egg presence/absence. Models for cod

682 spawning distribution, whether they use eggs or ripe and running adults as response, appear 
683 to be difficult to define as even a far larger number of covariates barely yielded double the 684 explained deviation (González-Irusta and Wright 2016a). Considering that the cod stock is 685 currently the most vulnerable one in the North Sea, the investigation of further drivers 686 governing the spawning distribution should concentrate on this species. Performance of 687 individual covariates indicates that the occurrence of spawning in a given location of the 688 North Sea is more dependent on covariates that do not vary over time, as the most important 689 covariates for these models were year day and bottom depth. Contrary, egg densities were to 690 a greater extent governed by covariates that change over time. This suggests that changes in 691 the ocean climate, not exceeding the fishes' physiological limits, may cause centres of 692 abundance to shift within spawning areas that remain the same. Such centres of abundance 693 should be avoided by potentially damaging activities, and aggregate maps of spawning 694 habitats and egg distributions, such as in the present study and Lelièvre et al. (2014), would 695 be valuable tools in the management of marine areas, protecting the successful reproduction 696 of fishes.

697

\section{Supplements}

699 Surface and bottom hydrography as well as the distribution of development stages for

700 individual years are available as online supplements (Figs S1-S4). Supplementary figures

701 presenting predicted versus observed values illustrate the information on predictive power of 702 individual covariates given in Table 4 (Figs S5-S8).

703

704 Acknowledgements

705 For the coordination of the surveys, to the Planning Group on North Sea Egg Surveys 706 (PGEGGS), ICES. Captains, crews and scientific staff of the participating research vessels

707 from Denmark, France, Germany, the Netherlands, Norway, Scotland and England. Stéphanie 
708 Lelièvre, Christophe Loots and Sandrine Vaz received additional financial support from the

709 INTERREG IVA France (Channel) - England cross-border European cooperation

710 programme, cofinanced by the European Regional Development Fund as part of the Channel

711 integrated Approach for marine Resource Management (CHARM) Phase 3 project. Hannes

712 Höffle was funded by the projects; Sustainable fisheries, climate change and the North Sea

713 ecosystem (SUNFISH, Danish Research Council Project 38135) and High-Resolution and

714 Dynamic Mapping of North Sea Spawning and Larvae Areas (KINO, Statoil and IMR,

715 project 14507). Richard Nash was supported by IMR's North Sea Programme, Early life

716 history dynamics of North Sea fishes (14387) and High-Resolution and Dynamic Mapping of

717 North Sea Spawning and Larvae Areas (KINO, Statoil and IMR, project 14507). The authors

718 would also like to thank the editor and two anonymous reviewers for their helpful

719 suggestions. 


\section{References}

721 Akaike, H. 1974. A New Look at the Statistical Model Identification. IEEE Trans. Autom. Control

722 AC19: 716-723.

723 Aurich, H.J. 1941. Die Verbreitung der pelagischen Fischbrut in der südlichen Nordsee während der

724 Frühjahrsfahrten, 1926-1937. DBB Z. Lebensr. 2: 183-225.

725 Bakun, A. 1996. Patterns in the ocean: Ocean processes and marine population dynamics. University 726 of California, San Diego.

727 Barton, K. 2013. MuMIn: Multi-model inference. R package version 1.9.5.

728 Beare, D.J., and Reid, D.G. 2002. Investigating spatio-temporal change in spawning activity by

729 Atlantic mackerel between 1977 and 1998 using generalized additive models. ICES J. Mar. Sci. 59:

$730 \quad 711-724$.

731 Bellier, E., Monestiez, P., Durbec, J.P., and Candau, J.N. 2007. Identifying spatial relationships at

732 multiple scales: principal coordinates of neighbour matrices (PCNM) and geostatistical approaches.

733 Ecography 30: 385-399.

734 Bigot, J.L. 1979. Identification des zoés de tourteau (Cancer pagurus L.) et d'étrille (Macropipus

735 puber L.), comparaison avec d'autres zoés de morphologie très voisine. ICES CM 1979/L:17,

736 International Council for the Exploration of the Sea, Copenhagen, DK.

737 Blanchet, F.G., Legendre, P., and Borcard, D. 2008. Forward selection of explanatory variables.

738 Ecology 89: 2623-2632.

739 Borcard, D., and Legendre, P. 2002. All-scale spatial analysis of ecological data by means of principal 740 coordinates of neighbour matrices. Ecol. Model. 153: 51-68.

741 Borcard, D., Gillet, F., and Legendre, P. 2011. Numerical ecology with R. Springer, New York. 
742 Brander, K.M. 1994. The Location and Timing of Cod Spawning Around the British Isles. ICES J.

743 Mar. Sci. 51: 71-89.

744 Bunn, N.A., Fox, C.J., and Webb, T. 2000. A literature review of studies on fish egg mortality:

745 Implications for the estimation of spawning stock biomass by the annual egg production method. Sci.

746 Ser., Tech. Rep. (111), CEFAS, Lowestoft, UK.

747 Charrier, G., Coombs, S.H., McQuinn, I.H., and Laroche, J. 2007. Genetic structure of whiting

748 Merlangius merlangus in the northeast Atlantic and adjacent waters. Mar. Ecol. Prog. Ser. 330: 201-

749211.

750 Collins, M., Knutti, R., Arblaster, J., Dufresne, J., Fichefet, T., Friedlingstein, P., Gao, X., Gutowski,

751 W., Johns, T., Krinner, G., Shongwe, M., Tebaldi, C., Weaver, A.J., and Michael, W. 2013. Long-

752 term climate change: Projections, commitments and irreversibility. In Climate change 2013: The

753 physical science basis. contribution of working group I to the fifth assessment report of the

754 intergovernmental panel on cliamte change. Edited by T.F. Stocker, D. Quin, G.-. Plattner, M. Tignor,

755 S.K. Allen, J. Boschung, A. Naules, Y. Xia, V. Bex and P.M. Midgley. Cambridge University Press,

756 Cambridge, United Kingdom and New York NY, USA.

757 Coombs, S.H., Nichols, J.H., and Fosh, C.A. 1990. Plaice eggs (Pleuronectes platessa L.) in the

758 southern North Sea: abundance, spawning area, vertical distribution, and buoyancy. J. Cons. Int.

759 Explor. Mer. 47: 133-139.

760 Coull, K.A., Johnstone, R., and Rogers, S.I. 1998. Fisheries sensitivity maps in british waters.

761 UKOOA Ltd, 1998, Aberdeen, Scotland.

762 Cushing, D.H. 1990. Hydrographic containment of a spawning group of plaice in the Southern Bight

763 of the North Sea. Mar. Ecol. Prog. Ser. 58: 287-297.

764 Daan, N. 1978. Changes in cod stocks and cod fisheries in the North Sea. Rapp. P. -V. Réun. Cons.

765 Int. Explor. Mer 172: 39-57. 
766 Daan, N., Heessen, H., Hislop, J.R.G., and Parnell, W. 1981. Results of the international 0-group 767 gadoid survey in the north sea, 1981.

768 Damas, D. 1909. Contribution à la biologie des gadides. Rapp. P. -V. Réun. Cons. Int. Explor. Mer 769 10: 1-227.

770 De Groot, S.d. 1996. Quantitative assessment of the development of the offshore oil and gas industry 771 in the North Sea. ICES J. Mar. Sci. 53: 1045-1050.

772 de la Cruz, M. 2008. Metodos para analizar datos puntuales. In Introducción al análisis espacial de 773 datos en ecología y ciencias ambientales: Métodos y aplicaciones. Edited by Maestre, F. T., Escudero, 774 A. y Bonet, A. Asociacion Espanola de Ecologia Terrestre, Universidad Rey Juan Carlos y Caja de 775 Ahorros del Mediterraneo Asociacion Espanola de Ecologia Terrestre, Universidad Rey Juan Carlos y 776 Caja de Ahorros del Mediterraneo, Madrid, ES. pp. 75-127.

Diniz-Filho, J.A.F., Bini, L.M., and Hawkins, B.A. 2003. Spatial autocorrelation and red herrings in 778 geographical ecology. Global Ecol. Biogeogr. 12(1): 53-64.

Dray, S., with contributions of Legendre, P., and Blanchet, G. 2013. packfor: Forward Selection with 780 permutation (Canoco p. 46) [online]. Available from https://r-forge.r-project.org/ [cited 12016 ].

781 Drinkwater, K.F. 2005. The response of Atlantic cod (Gadus morhua) to future climate change. ICES 782 J. Mar. Sci. 62: 1327-1337.

Dulvy, N.K., Rogers, S.I., Jennings, S., Stelzenmüller, V., Dye, S.R., and Skjoldal, H.R. 2008.

784 Climate change and deepening of the North Sea fish assemblage: a biotic indicator of warming seas. J.

785 Appl. Ecol. 45: 1029-1039.

786 Fox, C.J., Geffen, A.J., Blyth, R., and Nash, R.D.M. 2003. Temperature-dependent development rates 787 of plaice (Pleuronectes platessa L.) eggs from the Irish Sea. J. Plankton Res. 25: 1319-1329. 
788 Fox, C.J., Taylor, M., Dickey-Collas, M., Fossum, P., Kraus, G., Rohlf, N., Munk, P., van Damme, C.

789 J. G., Bolle, L.J., Maxwell, D.L., and Wright, P.J. 2008. Mapping the spawning grounds of North Sea

$790 \operatorname{cod}$ (Gadus morhua) by direct and indirect means. Proc. R. Soc. Lond. B 275: 1543-1548.

791 Fraser, J.H. 1968. Zooplankton sampling. 211, UNESCO, France.

792 Fritsch, M. 2005. Traits biologiques et exploitation du bar commun Dicentrarchus labrax (L.) dans le

793 pêcheries françaises de la manche et du golfe de gascogne. mémoire de thèse. Université de Bretagne

794 occidentale, Brest, FR.

795 Fromentin, J.M., and Planque, B. 1996. Calanus and environment in the eastern North Atlantic II.

796 Influence of the North Atlantic Oscillation on C. finmarchicus and C. helgolandicus. Mar. Ecol. Prog.

797 Ser. 134: 111-118.

798

Fujii, T. 2015. Temporal variation in environmental conditions and the structure of fish assemblages

799 around an offshore oil platform in the North Sea. 108: 69-82.

800 Geffen, A.J., Fox, C.J., and Nash, R.D.M. 2006. Temperature-dependent development rates of cod

801 Gadus morhua eggs. J. Fish Biol. 69: 1060-1080.

802 Geffen, A.J., and Nash, R.D.M. 2012. Egg development rates for use in egg production methods

803 (EPMs) and beyond. Fish. Res. 117-118: 48-62.

804 Gehringer, J.W. 1962. The Gulf III and other modern high-speed plankton samplers. Rapp. P. -V.

805 Réun. Cons. Int. Explor. Mer 153: 19-22.

806 Gilman, E., Chaloupka, M., Read, A., Dalzell, P., Holetschek, J., and Curtice, C. 2012. Hawaii

807 longline tuna fishery temporal trends in standardized catch rates and length distributions and effects

808 on pelagic and seamount ecosystems. Aquat. Conserv. : Mar. Freshwat. Ecosyst. 22(4): 446-488.

809 Goedecke, E., Smed, J., and Tomczak, G. 1967. Monatskarten des salzgehaltes der nordsee dargestellt

810 für verschiedene Tiefenhorizonte. Deutsches hydrographisches Institut, Hamburg. 
811 Golden Software. 2011. Surfer. Golden Software, Inc, Golden, CO.

812 González-Irusta, J., and Wright, P. 2016a. Spawning grounds of Atlantic cod (Gadus morhua) in the

813 North Sea. ICES J. Mar. Sci. 73(2): 304-315.

814 González-Irusta, J., and Wright, P. 2016b. Spawning grounds of haddock (Melanogrammus

815 aeglefinus) in the North Sea and West of Scotland. Fish. Res. 183: 180-191.

816 Graham, M. 1934. Report on the north sea cod. HM Stationery Office, London, UK.

817 Heath, M.R., Culling, M.A., Crozier, W.W., Fox, C.J., Gurney, W.S., Hutchinson, W.F., Nielsen,

818 E.E., O'Sullivan, M., Preedy, K.F., and Righton, D.A. 2014. Combination of genetics and spatial

819 modelling highlights the sensitivity of cod (Gadus morhua) population diversity in the North Sea to

820 distributions of fishing. ICES J. Mar. Sci. 71(4): 794-807.

821 Heath, M., Rankine, P., and Cargill, L. 1994. Distribution of cod and haddock eggs in the North Sea

822 in 1992 in relation to oceanographic features and compared with distributions in 1952-1957

823 (Abstract). ICES Mar. Sci. Symp. 198: 438-439.

824 Heath, M.R., and Gallego, A. 1998. Bio-physical modelling of the early life stages of haddock,

825 Melanogrammus aeglefinus, in the North Sea. Fish. Oceanogr. 7: 110-125.

826 Heath, M.R., Kunzlik, P.A., Gallego, A., Holmes, S., and Wright, P.J. 2008. A model of meta-

827 population dynamics for North Sea and West of Scotland cod - The dynamic consequences of natal

828 fidelity. 93: 92-116.

829 Hedger, R., McKenzie, E., Heath, M., Wright, P., Scott, B., Gallego, A., and Andrews, J. 2004.

830 Analysis of the spatial distributions of mature cod (Gadus morhua) and haddock (Melanogrammus

831 aeglefinus) abundance in the North Sea (1980-1999) using generalised additive models. Fish. Res. 70:

$832 \quad 17-25$. 
833 Hislop, J.R.G. 1984. A comparison of the reproductive tactics and strategies of cod, haddock, whiting

834 and norway pout in the north sea. In Fish reproduction: Strategies and tactics. Edited by G.W. Potts

835 and R.J. Wooton. Academic Press, Oxford. pp. 311-330.

836 Höffle, H., Solemdal, P., Korsbrekke, K., Johannessen, M., Bakkeplass, K., and Kjesbu, O.S. 2014.

837 Variability of northeast Arctic cod (Gadus morhua) distribution on the main spawning grounds in

838 relation to biophysical factors. ICES J. Mar. Sci. 71: 1317-1331.

839 Holmes, S.J., Millar, C.P., Fryer, R.J., and Wright, P.J. 2014. Gadoid dynamics: differing perceptions

840 when contrasting stock vs. population trends and its implications to management. ICES J. Mar. Sci.

841 71(6): 1433-1442.

842 Houghton, R., and Harding, D. 1976. The plaice of the English Channel: spawning and migration. J.

843 Cons. Int. Explor. Mer. 36: 229-239.

844 Hufnagl, M., Peck, M.A., Nash, R.D., Pohlmann, T., and Rijnsdorp, A.D. 2013. Changes in potential

845 North Sea spawning grounds of plaice (Pleuronectes platessa L.) based on early life stage

846 connectivity to nursery habitats. J. Sea Res. 84: 26-39.

847 Hunter, E., Metcalfe, J., Arnold, G., and Reynolds, J. 2004. Impacts of migratory behaviour on

848 population structure in North Sea plaice. J. Anim. Behav. 73: 377-385.

849 ICES. 2009. ICES dataset on ocean hydrography.

850 ICES. 2008. Report of the planning group on north sea cod and plaice egg surveys (PGEGGS), 13-14

851 may 2008, Lowestoft, UK.

852 Kelley, D. 2013. Oce: Analysis of oceanographic data.

853 Laurence, G.C., and Rogers, C.A. 1976. Effects of temperature and salinity on comparative embryo

854 development and mortality of Atlantic cod (Gadus morhua L.) and haddock

855 (Melanogrammus aeglefinus L.). J. Cons. Int. Explor. Mer. 36: 220-228. 
856 Legendre, P., Borcard, D., Blanchet, G., and Dray, S. 2013. PCNM: MEM spatial eigenfunction and 857 principal coordinate analyses.

858 Lelièvre, S. 2010. Identification and characterisation of winter spawning ground in the english 859 channel and southern north sea. PhD, Université de Nantes, Nantes, FR.

860 Lelièvre, S., Verrez-Bagnis, V., Jerome, M., and Vaz, S. 2010. PCR-RFLP analyses of formalin-fixed 861 fish eggs for the mapping of spawning areas in the Eastern Channel and Southern North Sea. J.

862 Plankton Res. 32: 1527-1539.

863 Lelièvre, S., Vaz, S., and Fox, C. 2012. The effectiveness of the continuous underway fish egg

864 sampler compared with standard vertical plankton hauls for sampling the eggs of demersal species in 865 the southern North Sea. Fish. Oceanogr. 21: 109-124.

866 Lelièvre, S., Vaz, S., Martin, C., and Loots, C. 2014. Delineating recurrent fish spawning habitats in 867 the North Sea. J. Sea Res. 91: 1-14.

868 Løkkeborg, S., Humborstad, O., Jørgensen, T., and Soldal, A.V. 2002. Spatio-temporal variations in 869 gillnet catch rates in the vicinity of North Sea oil platforms. ICES Journal of Marine Science: Journal 870 Du Conseil 59(suppl): S294-S299.

871 Loots, C., Vaz, S., Planque, B., and Koubbi, P. 2011a. Understanding what controls the spawning 872 distribution of North Sea whiting (Merlangius merlangus) using a multi-model approach. Fish. 873 Oceanogr. 20: 18-31.

874 Loots, C., Sandrine, V., Planque, B., and Koubbi, P. 2011b. Spawning distribution of North Sea plaice 875 and whiting from 1980 to 2007. J. Oceanogr. 3: 77-95.

876 Loots, C., Vaz, S., Planque, B., and Koubbi, P. 2010a. What controls the spatial distribution of the 877 North Sea plaice spawning population? Confronting ecological hypotheses through a model selection 878 framework. ICES J. Mar. Sci. 67: 244-257. 
879 Loots, C., Vaz, S., Koubbi, P., Planque, B., Coppin, F., and Verin, Y. 2010b. Inter-annual variability

880 of North Sea plaice spawning habitat. J. Sea Res. 64: 427-435.

881 Mastail, M., and Battaglia, A. 1978. Amélioration de la conservation des pigments du zooplancton.

882 CM 1978/L:20, Conseil international pour l'Exploration de la Mer, Roscoff, FR.

883 McCauley, R.D., Production, A.P., and Association, E. 2000. Marine seismic surveys: a study of

884 environmental implications. Appea J. 40: 692-708.

885 Metcalfe, J. 2006. Fish population structuring in the North Sea: understanding processes and

886 mechanisms from studies of the movements of adults. J. Fish Biol. 69: 48-65.

887 Millero, F.J., and Poisson, A. 1981. International One-Atmosphere Equation of State of Seawater.

888 Deep Sea Res. Pt. A 28: 625-629.

889 Ministerie van Economische Zaken. 2015. NL Olie- en Gasportaal [online]. Available from

890 http://www.nlog.nl/nl/pubs/maps/other_maps/other_maps.html [cited 06 2015].

891 Munk, P., Wright, P.J., and Pihl, N.J. 2002. Distribution of the early larval stages of cod, plaice and

892 lesser sandeel across haline fronts in the North Sea. Coast. Shelf Sci. 55: 139-149.

893 Munk, P., Larsson, P.O., Danielssen, D.S., and Moksness, E. 1999. Variability in frontal zone

894 formation and distribution of gadoid fish larvae at the shelf break in the northeastern North Sea. Mar.

895 Ecol. Prog. Ser. 177: 221-233.

896 Munk, P., Fox, C.J., Bolle, L.J., van Damme, C.J.G., Fossum, P., and Kraus, G. 2009. Spawning of

897 North Sea fishes linked to hydrographic features. 18: 458-469.

898 Munk, P., and Nielsen, J. 2005. Eggs and larvae of north sea fishes. Biofolia, Frederiksberg, DK.

899 Nash, R.D.M., Dickey-Collas, M., and Milligan, S.P. 1998. Descriptions of the Gulf VII/PRO-NET

900 and MAFF/Guildline unencased high-speed plankton samplers. J. Plankton Res. 20: 1915-1926. 
901 Neat, F., and Righton, D. 2007. Warm water occupancy by North Sea cod. Proc. R. Soc. Lond. B 274: $902 \quad 789-798$.

903 Nellen, V.M., and Hempel, G. 1969. Versuche zur Fängigkeit des 'Hai' und des modifizierten Gulf-V904 Plankton-Samplers 'Nackthai'/comparisons of the fishing efficiency of the Gulf III sampler 'Hai' and a 905 modfied sampler 'Nackthai'. Meeresforsch. 20: 141-154.

906 NOAA (NGDC). 2016a. Bathymetry and Global Relief [online]. Available from

907 https://www.ngdc.noaa.gov/mgg/bathymetry/relief.html [cited 6 2016].

908 NOAA (NGDC). 2016b. Shoreline / Coastline Resources [online]. Available from

909 https://www.ngdc.noaa.gov/mgg/shorelines/ [cited 6 2016].

910 Oksanen, J., Blanchet, F.G., Kindt, R., Legendre, P., O'Hara, R.B., Simpson, G.L., Solymos, P.,

911 Stevens, M.H.H., and Wagner, H. 2013. Vegan: Community ecology package.

912 Oljedirektoratet. 2015. Seismic surveys [online]. Available from

913 http://gis.npd.no/arcgis/rest/services/FactMaps/2_0/MapServer/7 [cited 6 2015].

914 OSPAR Commission. 2014. Inventory of Offshore Installations [online]. Available from

915 http://www.ospar.org/data [cited 7 2016].

916 Ottersen, G., Hjermann, D.O., and Stenseth, N.C. 2006. Changes in spawning stock structure

917 strengthen the link between climate and recruitment in a heavily fished cod (Gadus morhua) stock.

918 Fish. Oceanogr. 15: 230-243.

919 Otto, L., and Zimmerman, J.T.F. 1990. Review of the physical oceanography of the North Sea Part 1.

920 General review. Neth. J. Sea Res. 26: 163-193.

921 Payne, J.F. 2004. Potential effect of seismic surveys on fish eggs, larvae and zooplankton. Canadian

922 Science Advisory Secretariat, St. John's, CA. 
923 Pebesma, E.J. 2004. Multivariate geostatistics in S: The gstat package.

924 Peres-Neto, P.R., Legendre, P., Dray, S., and Borcard, D. 2006. Variation partitioning of species data

925 matrices: Estimation and comparison of fractions. Ecology 87: 2614-2625.

926 Perry, A.L., Low, P.J., Ellis, J.R., and Reynolds, J.D. 2005. Climate change and distribution shifts in 927 marine fishes. Science 308: 1912-1915.

928 Petitgas, P., Rijnsdorp, A.D., Dickey $\square$ Collas, M., Engelhard, G.H., Peck, M.A., Pinnegar, J.K.,

929 Drinkwater, K., Huret, M., and Nash, R.D. 2013. Impacts of climate change on the complex life

930 cycles of fish. Fish. Oceanogr. 22(2): 121-139.

931 Planque, B., and Frédou, T. 1999. Temperature and the recruitment of Atlantic cod (Gadus morhua).

932 Can. J. Fish. Aquat. Sci. 56: 2069-2077.

933 Posgay, J., and Marak, R.R. 1980. The MARMAP bongo zooplankton samplers. J. Northw. Atl. Fish.

934 Sci 1: 91-99.

935 Povoa, I., Davie, A., Treasurer, J., and Migaud, H. 2011. Broodstock spawning and larviculture of

936 whiting (Merlangius merlangus L.) reared in captivity. Aquacult. Res. 42: 386-398.

937 Rijnsdorp, A. 1989. Maturation of male and female North Sea plaice (Pleuronectes platessa L.). J.

938 Cons. Int. Explor. Mer. 46: 35-51.

939 Rindorf, A., and Lewy, P. 2006. Warm, windy winters drive cod north and homing of spawners keeps

940 them there. J. Appl. Ecol. 43: 445-453.

941 Russell, F.S. 1976. The eggs and planktonic stages of British marine fishes. Academic Press, London, 942 UK.

943 Ryland, J.S., Nichols, J.H., and Sykes, A.M. 1975. Effect of temperature on embryonic development

944 of plaice, Pleuronectes platessa L. (Teleostei). J. Exp. Mar. Biol. Ecol. 18: 121-137. 
945 Schwarz, G. 1978. Estimating the dimension of a model. The Annals of Statistics 6(2): 461-464.

946 Sharples, J., Moore, C.M., Hickman, A.E., Holligan, P.M., Tweddle, J.F., Palmer, M.R., and Simpson, 947 J.H. 2009. Internal tidal mixing as a control on continental margin ecosystems. Geophys. Res. Lett. $948 \quad 36(23)$.

949 Simpson, J., Sharples, J., and Rippeth, T. 1991. A prescriptive model of stratification induced by 950 freshwater runoff. Estuar. Coast. Shelf Sci. 33(1): 23-35.

951 Simpson, J.H., Bos, W.G., Schirmer, F., Souza, A.J., Rippeth, T.P., Jones, S.E., and Hydes, D. 1993.

952 Periodic stratification in the Rhine Rofi in the North Sea. Oceanol. Acta 16: 23-32.

953 Smithies, M. 2014. A Review-Worldwide Guidelines to Mitigate the Effect of Seismic on Marine

954 Mammals. 76th EAGE Conference and Exhibition 2014, Amsterdam, NL,.

955 Software, G. 1999. Grid operations. In Surfer 7 user's guide. Edited by Golden Software, Inc, Golden. $956 \quad$ pp. 361-414.

957 Sündermann, J., and Pohlmann, T. 2011. A brief analysis of North Sea physics. Oceanologia 53(3):

$958 \quad 663-689$.

959 Syrjala, S.E. 1996. A statistical test for a difference between the spatial distributions of two

960 populations. Ecology 77: 75-80.

961 Taylor, M.I., Fox, C., Rico, I., and Rico, C. 2002. Species-specific TaqMan probes for simultaneous

962 identification of cod (Gadus morhua L.), haddock (Melanogrammus aeglefinus L.) and whiting

963 (Merlangius merlangus L.). Mol. Ecol. Notes 2: 599-601.

964 Taylor, N., Fox, C.J., Bolle, L.J., Dickey-Collas, M., Fossum, P., Kraus, G., Munk, P., Rohlf, N., van

965 Damme, C.J.G., and Vorbach, M. 2007. Results of the spring 2004 north sea ichthyoplankton

966 surveys: The distribution of fish eggs and larvae from the international ichthyoplankton survey. ICES 
967 Cooperative Research Report, 285, International Council for the Exploration of the Sea, Copenhagen,

968 DK.

969 Thompson, B.M., and Riley, J.D. 1981. Egg and larval development studies in the North Sea cod

970 (Gadus morhua L.). Rapp. P. -V. Réun. Cons. Int. Explor. Mer 178: 553-559.

971 Thompson, H. 1928. Haddock biology. International Council for the Exploration of the Sea,

972 Copenhagen, DK.

973 Tomczak, G., and Goedecke, E. 1962. Monatskarten der Temperatur der Nordsee dargestellt für

974 verschiedene Tiefenhorizonte. Ergaenzung. Deutsch. Hydrogr. Zeitschr. 7: 1-112.

975 Tranter, D.J. 1968. Zooplankton sampling. UNESCO Report. Monographs on Oceanographic

976 Methodology No. 2, Paris, FR.

977 Wahlberg, M., and Westerberg, H. 2005. Hearing in fish and their reactions to sounds from offshore

978 wind farms. Mar. Ecol. Prog. Ser. 288: 295-309.

979 Wegner, G., Damm, U., and Purps, M. 2003. Physical influences on the stock dynamics of plaice and

980 sole in the North Sea. Scient. Mar. 67: 219-234.

981 Wood, S.N. 2006. Generalized additive models: An introduction with R. Chapman \& Hall, London, 982 UK.

983 Wood, S., and Scheipl, F. 2014. Gamm4: Generalized additive mixed models using mgev and lme4. R 984 package version 0.2-3.

985 Zuur, A.F. 2010. AED: Data files used in mixed effects models and extensions in ecology with R.

986 (2009).

987 Zuur, A.F., Ieno, E.N., Walker, N.J., Saveliev, A.A., and Smith, G.M. 2009. Mixed effects models

988 and extension in ecology with R. Springer Science and Business Media, New York. 
Table 1: Survey cruises in this study. For the BONGO nets only the mesh size for the samples used in the analysis is given.

990

\begin{tabular}{|c|c|c|c|c|c|c|c|c|}
\hline Year & Country & Survey $^{a}$ & Ship & Start Date & End Date & Gear & Mesh size $(\mu \mathrm{m})$ & Nos. Hauls \\
\hline \multirow[t]{5}{*}{2004} & NL & PLACES & Tridens II & 1.3 .04 & 4.3 .04 & Gulf VII & 270 & 64 \\
\hline & $\mathrm{DE}$ & PLACES & Heinke & 16.2 .04 & 23.2 .04 & BONGO & 500 & 51 \\
\hline & UK & PLACES & Corystes & 18.2 .04 & 8.3 .04 & Gulf VII & 270 & 137 \\
\hline & DK & PLACES & Dana & 25.2 .04 & 6.3 .04 & BONGO & 330 & 100 \\
\hline & NO & PLACES & Haakon Mosby & 8.3 .04 & 23.3 .04 & Gulf III & 330 & 86 \\
\hline \multirow[t]{5}{*}{2009} & $\mathrm{SC}$ & PGEGGS & Scotia & 20.2 .09 & 6.3 .09 & BONGO & 350 & 53 \\
\hline & FR & add. IBTS & Thalassa & 17.1.09 & 13.2.09 & WP2 & 500 & 136 \\
\hline & $\mathrm{NO}$ & add. IBTS & G. O. Sars & 8.2 .09 & 21.2 .09 & Gulf VII & 280 & 57 \\
\hline & $\mathrm{NL}$ & IHLS & Tridens II & 19.1.09 & 22.1 .09 & Gulf VII & 280 & 69 \\
\hline & DK & add. IBTS & Dana & 31.1 .09 & 17.2.09 & BONGO & 330 & 68 \\
\hline
\end{tabular}

991

$992^{a}$ ) Abbreviations: add. IBTS = Additional IBTS-Sampling, IHLS = International Herring Larvae Surveys, PLACES = Plaice and Cod Egg

993 Surveys, PCEGGS = Planning Group on North Sea Cod and Plaice Egg Surveys 
994 Table 2: Syrjala-test between Stage I and subsequent development stages, for each year and both years combined. P $<0.5$ indicates

995 that the distribution patters are significantly dissimilar.

996

\begin{tabular}{|c|c|c|c|c|c|c|c|c|c|c|c|c|c|c|c|c|}
\hline & \multicolumn{4}{|c|}{ Stage II } & \multicolumn{4}{|c|}{ Stage III } & \multicolumn{4}{|c|}{ Stage IV } & \multicolumn{4}{|c|}{ Stage V } \\
\hline & \multirow{2}{*}{\multicolumn{2}{|c|}{$\begin{array}{c}\text { Cramér-von } \\
\text { Mises }\end{array}$}} & \multirow{2}{*}{\multicolumn{2}{|c|}{$\begin{array}{c}\text { Kolmogorov } \\
\text { - Smirnov }\end{array}$}} & \multirow{2}{*}{\multicolumn{2}{|c|}{$\begin{array}{c}\text { Cramér-von } \\
\text { Mises }\end{array}$}} & \multirow{2}{*}{\multicolumn{2}{|c|}{$\begin{array}{l}\text { Kolmogorov } \\
\text { - Smirnov }\end{array}$}} & \multirow{2}{*}{\multicolumn{2}{|c|}{$\begin{array}{c}\text { Cramér-von } \\
\text { Mises }\end{array}$}} & \multirow{2}{*}{\multicolumn{2}{|c|}{$\begin{array}{l}\text { Kolmogorov } \\
\text { - Smirnov }\end{array}$}} & \multirow{2}{*}{\multicolumn{2}{|c|}{$\begin{array}{c}\text { Cramér-von } \\
\text { Mises }\end{array}$}} & \multirow{2}{*}{\multicolumn{2}{|c|}{$\begin{array}{l}\text { Kolmogorov } \\
\text { - Smirnov }\end{array}$}} \\
\hline & & & & & & & & & & & & & & & & \\
\hline & $\Psi$ & $\mathbf{p}$ & $\Psi$ & $\mathbf{p}$ & $\Psi$ & $\mathbf{p}$ & $\Psi$ & $\mathbf{p}$ & $\Psi$ & $\mathbf{p}$ & $\Psi$ & $\mathbf{p}$ & $\Psi$ & $\mathbf{p}$ & $\Psi$ & $\mathbf{p}$ \\
\hline \multicolumn{17}{|l|}{2004} \\
\hline Cod & 1.58 & 0.072 & 0.18 & 0.067 & 0.70 & 0.546 & 0.13 & 0.532 & 3.92 & 0.181 & 0.28 & 0.139 & 4.40 & 0.114 & 0.29 & 0.032 \\
\hline Haddock & 2.85 & 0.004 & 0.22 & 0.018 & 1.36 & 0.061 & 0.16 & 0.098 & 3.78 & 0.004 & 0.26 & 0.012 & 4.91 & 0.003 & 0.33 & 0.001 \\
\hline Whiting & 4.14 & 0.014 & 0.22 & 0.038 & 2.21 & 0.221 & 0.23 & 0.491 & 7.27 & 0.073 & 0.28 & 0.274 & 22.5 & 0.032 & 0.47 & 0.024 \\
\hline Plaice & 0.44 & 0.254 & 0.11 & 0.362 & 1.01 & 0.061 & 0.12 & 0.345 & 3.39 & 0.001 & 0.26 & 0.002 & 4.67 & 0.001 & 0.31 & 0.002 \\
\hline \multicolumn{17}{|l|}{2009} \\
\hline Cod & 5.62 & 0.097 & 0.33 & 0.073 & 5.42 & 0.062 & 0.35 & 0.062 & 7.09 & 0.016 & 0.38 & 0.011 & 5.12 & 0.076 & 0.35 & 0.049 \\
\hline Haddock & 1.25 & 0.170 & 0.27 & 0.179 & 1.02 & 0.202 & 0.27 & 0.091 & 0.67 & 0.309 & 0.17 & 0.488 & 2.04 & 0.107 & 0.33 & 0.115 \\
\hline Whiting & 0.84 & 0.018 & 0.25 & 0.203 & 0.67 & 0.075 & 0.25 & 0.133 & 1.59 & 0.06 & 0.36 & 0.305 & 2.52 & 0.112 & 0.54 & 0.101 \\
\hline
\end{tabular}




\begin{tabular}{|c|c|c|c|c|c|c|c|c|c|c|c|c|c|c|c|c|}
\hline Plaice & 4.65 & 0.058 & 0.36 & 0.061 & 1.49 & 0.144 & 0.22 & 0.135 & 0.92 & 0.142 & 0.19 & 0.091 & 2.38 & 0.098 & 0.30 & 0.051 \\
\hline \multicolumn{17}{|l|}{ Mean } \\
\hline Cod & 3.33 & 0.089 & 0.16 & 0.159 & 2.06 & 0.219 & 0.17 & 0.146 & 6.69 & 0.019 & 0.30 & 0.016 & 4.41 & 0.082 & 0.21 & 0.113 \\
\hline Haddock & 3.10 & 0.01 & 0.17 & 0.042 & 1.56 & 0.116 & 0.14 & 0.153 & 4.64 & 0.012 & 0.24 & 0.022 & 6.98 & 0.006 & 0.32 & 0.005 \\
\hline Whiting & 2.43 & 0.066 & 0.20 & 0.070 & 3.40 & 0.104 & 0.24 & 0.069 & 7.99 & 0.048 & 0.31 & 0.13 & 15.72 & 0.072 & 0.37 & 0.111 \\
\hline Plaice & 1.43 & 0.144 & 0.15 & 0.138 & 0.44 & 0.521 & 0.08 & 0.702 & 2.10 & 0.049 & 0.19 & 0.009 & 3.27 & 0.062 & 0.21 & 0.052 \\
\hline
\end{tabular}


998 Table 3: Model formulae, explained deviation, AIC, BIC and Moran's I in the residuals for the best fitting GAMMs fit to presence/absence 999 and density of fish eggs. Of the Moran's I only the values for the first lag are presented.

1000

\begin{tabular}{|c|c|c|c|c|c|c|c|}
\hline Species & Type & $\mathbf{N}$ & Model Formula $^{a}$ & GAM - Dev. Expl. (\%) & AIC & BIC & Moran's I $^{b}$ \\
\hline \multirow[t]{2}{*}{ Cod } & Presence/absence & 696 & YD + s(b_depth, 4) + s5, (1|MEV2) + (1|MEV5) & 18.5 & 688.1 & 720 & $0.04 * *$ \\
\hline & Egg density & 510 & $\mathrm{~s}(\mathrm{YD}, 4)+\mathrm{s}\left(\mathrm{b} \_\right.$depth, 4) $+\mathrm{s}(\mathrm{t} 5,4),(1 \mid \mathrm{MEV} 2)+(1 \mid \mathrm{MEV} 5)$ & 14.6 & 1131.2 & 1173.6 & $0.23 * *$ \\
\hline \multirow[t]{2}{*}{ Haddock } & Presence/absence & 696 & $\begin{array}{l}\mathrm{s}(\mathrm{YD}, 4)+\mathrm{s}\left(\mathrm{b} \_ \text {depth, } 4\right)+\mathrm{s}(\mathrm{tb}, 4)+\mathrm{cs} .(\mathrm{sb})+\sigma_{\mathrm{t}} \mathrm{gb} \\
(1 \mid \mathrm{MEV} 3)+(1 \mid \mathrm{MEV} 10)+(1 \mid \mathrm{MEV} 28)+(1 \mid \mathrm{MEV} 83)\end{array}$ & 57.3 & 478.5 & 537.6 & $0.07 * *$ \\
\hline & Egg density & 336 & $\begin{array}{l}\mathrm{YD}+\mathrm{s}\left(\mathrm{b} \_ \text {depth, 3) }+\mathrm{s}(\mathrm{tb}, 3)+\mathrm{s}(\mathrm{sb}, 3)+\sigma_{\mathrm{t}} \mathrm{gb}\right. \\
(1 \mid \mathrm{MEV} 3)+(1 \mid \mathrm{MEV} 10)+(1 \mid \mathrm{MEV} 28)+(1 \mid \mathrm{MEV} 83)\end{array}$ & 42.6 & 725.3 & 778.7 & $0.05 * *$ \\
\hline \multirow[t]{2}{*}{ Whiting } & Presence/absence & 696 & $\mathrm{~s}(\mathrm{YD}, 4)+\mathrm{b} \_$depth $+\mathrm{tb}+\mathrm{s}\left(\sigma_{\mathrm{t}} \mathrm{gb}, 4\right),(1 \mid \mathrm{MEV} 2)$ & 29.8 & 672.8 & 709.2 & $0.02 *$ \\
\hline & Egg density & 448 & $\mathrm{~s}(\mathrm{YD}, 4)+\mathrm{s}\left(\mathrm{b} \_\right.$depth, 4$)+\mathrm{s}(\mathrm{t} 5,4)+\mathrm{s}(\mathrm{s} 5,4)+\sigma_{\mathrm{t}} \mathrm{g} 5,(1 \mid \mathrm{MEV} 2)$ & 34.8 & 1081.8 & 1131.0 & $0.12 * *$ \\
\hline \multirow[t]{2}{*}{ Plaice } & Presence/absence & 696 & $\begin{array}{l}\mathrm{s}(\mathrm{YD}, 4)+\mathrm{s}\left(\mathrm{b} \_ \text {depth, 4) }+\mathrm{tb}\right. \\
(1 \mid \mathrm{MEV} 2)+(1 \mid \mathrm{MEV} 8)+(1 \mid \mathrm{MEV} 12)+(1 \mid \mathrm{MEV} 15)\end{array}$ & 21.4 & 808 & 853.5 & $0.02 * *$ \\
\hline & Egg density & 363 & $\begin{array}{l}\mathrm{s}(\mathrm{YD}, 4)+\mathrm{s}\left(\mathrm{b} \_ \text {depth }, 4\right)+\mathrm{s}(\mathrm{t} 5,4)+\mathrm{s}(\mathrm{s} 5,4)+\sigma_{\mathrm{t}} \mathrm{g} 5 \\
(1 \mid \mathrm{MEV} 2)+(1 \mid \mathrm{MEV} 8)+(1 \mid \mathrm{MEV} 12)+(1 \mid \mathrm{MEV} 15)\end{array}$ & 29.3 & 655.1 & 713.5 & $0.18 * *$ \\
\hline
\end{tabular}


$1002^{a}$ ) Model formulae show the fixed-effects covariates, either as linear or smooth $(\mathrm{s}())$ terms with degrees of freedom. The prefix cs. indicates 1003 a scaling function applied to a linear term. Explained devation was calculated with a GAM using the same fixed effects. MEVs were 1004 included as random covariates, e.g. (1|MEV1). YD, day of the year; b_depth, bottom depth; t5, temperature at $5 \mathrm{~m}$ depth; s5, salinity at $5 \mathrm{~m}$ 1005 depth; $\sigma_{\mathrm{t}} \mathrm{g} 5$, gradient of $\sigma_{\mathrm{t}}$ at 5 depth; tb, bottom temperature; sb, bottom salinity; $\sigma_{\mathrm{t}} \mathrm{gb}$, gradient of $\sigma_{\mathrm{t}}$ at the bottom. MEVs

1006 b) Significance levels: **: $\leq 0.001, *:>0.001$ 
1007 Table 4: Predictive performance of the selected models and single covariates. The

1008 performance for presence/absence models is given as Receiver Operating

1009 Characteristic Area Under the Curve (ROC AUC) while for the egg densities it is the

$1010 \quad r^{2}$ between predictions and observations. $\mathrm{N}$ is 636 for presence/absence of all

1011 species, for the non-zero abundance it is: $\mathrm{N}_{\text {Cod }}=510, \mathrm{~N}_{\text {Haddock }}=336$, $\mathrm{N}_{\text {Whiting }}=448$,

$1012 \quad N_{\text {Plaice }}=363$.

1013

\begin{tabular}{|c|c|c|c|c|c|}
\hline Response & Covariates $^{a}$ & Cod & Haddock & Whiting & Plaice \\
\hline \multirow[t]{10}{*}{ Presence/Absence (ROC AUC) } & Selected Model & 0.71 & 0.85 & 0.79 & 0.74 \\
\hline & Year Day & 0.64 & 0.78 & 0.72 & 0.63 \\
\hline & Bottom Depth & 0.54 & 0.77 & 0.50 & 0.71 \\
\hline & Temperature5 & - & - & - & - \\
\hline & Salinity5 & 0.50 & - & - & - \\
\hline & $\sigma_{\mathrm{t}}$-Gradient5 & - & - & - & - \\
\hline & Temperatureb & - & 0.77 & 0.60 & 0.63 \\
\hline & Salinityb & - & 0.81 & & - \\
\hline & $\sigma_{\mathrm{t}}$-Gradientb & - & 0.63 & 0.62 & - \\
\hline & Random & 0.50 & 0.50 & 0.50 & 0.50 \\
\hline \multirow[t]{5}{*}{ Egg Density $\left(r^{2}\right)$} & Selected Model & 0.45 & 0.62 & 0.72 & 0.51 \\
\hline & Year Day & 0.38 & 0.38 & 0.59 & 0.35 \\
\hline & Bottom Depth & 0.42 & 0.56 & 0.61 & 0.39 \\
\hline & Temperature5 & 0.42 & - & 0.57 & 0.43 \\
\hline & Salinity5 & - & - & 0.58 & 0.38 \\
\hline
\end{tabular}




$\begin{array}{lcccc}\sigma_{\mathrm{t}}-\text { Gradient5 } & - & - & 0.59 & 0.31 \\ \text { Temperatureb } & - & 0.50 & - & - \\ \text { Salinityb } & - & 0.53 & - & - \\ \sigma_{\mathrm{t}} \text {-Gradientb } & - & 0.35 & - & - \\ \text { Random } & 0.36 & 0.34 & 0.56 & 0.30\end{array}$

1014

1015 a) Suffixes 5 and $\mathrm{b}$ indicate whether a value was measured at the surface $(5 \mathrm{~m})$ or at 1016 the bottom. 
1017 Table 5: Log-likelihood ratio test between the selected models and models with

1018 each of the covariates removed in turn. Bold font indicates significant p-values.

1019

\begin{tabular}{|c|c|c|c|c|c|c|c|}
\hline \multirow{2}{*}{ Species } & \multirow{2}{*}{ Dropped Covariate $^{a}$} & \multicolumn{3}{|c|}{ Presence/Absence } & \multicolumn{3}{|c|}{ Egg density } \\
\hline & & $\chi^{2} 0.05$ & df & $\mathbf{p}$ & $\chi^{2} 0.05$ & df & $\mathbf{p}$ \\
\hline \multirow[t]{5}{*}{ Cod } & Year Day & 124.0 & 1 & $<0.001$ & 2.2 & 1 & 0.13 \\
\hline & Bottom Depth & 37.1 & 2 & $<0.001$ & 10.2 & 1 & 0.001 \\
\hline & Temperature5 & - & - & - & 13.8 & 1 & $<0.001$ \\
\hline & Salinity5 & 5.0 & 1 & 0.026 & - & - & - \\
\hline & $\sigma_{\mathrm{t}}$-Gradient5 & - & - & - & - & - & - \\
\hline \multirow[t]{5}{*}{ Haddock } & Year Day & 181.0 & 2 & $<0.001$ & 4.8 & 1 & 0.029 \\
\hline & Bottom Depth & 12.0 & 2 & 0.003 & 14.6 & 2 & 0.001 \\
\hline & Temperatureb & 35.3 & 2 & $<0.001$ & 0.9 & 2 & 0.622 \\
\hline & Salinityb & 40.4 & 1 & $<0.001$ & 15.9 & 2 & $<0.001$ \\
\hline & $\sigma_{\mathrm{t}}$-Gradientb & 6.7 & 1 & 0.097 & 14.3 & 1 & $<0.001$ \\
\hline \multirow[t]{8}{*}{ Whiting } & Year Day & 134.9 & 2 & $<0.001$ & 32.6 & 2 & $<0.001$ \\
\hline & Bottom Depth & 82.4 & 1 & $<0.001$ & 79.6 & 2 & $<0.001$ \\
\hline & Temperature5 & - & - & - & 24.1 & 2 & $<0.001$ \\
\hline & Salinity 5 & - & - & - & 0.8 & 2 & 0.658 \\
\hline & $\sigma_{\mathrm{t}}-$ Gradient5 & - & - & - & 5.4 & 1 & 0.020 \\
\hline & Temperatureb & 34.1 & 1 & $<0.001$ & - & - & - \\
\hline & Salinityb & - & - & - & - & - & - \\
\hline & $\sigma_{t^{-}}$Gradientb & 2.0 & 2 & 0.374 & - & - & - \\
\hline
\end{tabular}




\begin{tabular}{llcccccc}
\hline Plaice & Year Day & 35.5 & 2 & $<\mathbf{0 . 0 0 1}$ & 3.5 & 2 & 0.172 \\
Bottom Depth & 78.2 & 2 & $<\mathbf{0 . 0 0 1}$ & 3.4 & 2 & 0.181 \\
Temperature5 & - & - & - & 19.1 & 2 & $<\mathbf{0 . 0 0 1}$ \\
Salinity5 & - & - & - & 1.8 & 2 & 0.408 \\
$\sigma_{\mathrm{t}}$-Gradient5 & - & - & - & 0.6 & 1 & 0.426 \\
Temperatureb & 9.5 & 1 & $\mathbf{0 . 0 0 2}$ & - & - & - \\
Salinityb & - & - & - & - & - & - \\
& $\sigma_{\mathrm{t}}$-Gradientb & - & 1 & - & - & - & - \\
\hline
\end{tabular}

1020

$1021^{a}$ ) Suffixes 5 and $\mathrm{b}$ indicate whether a value was measured at the surface $(5 \mathrm{~m})$ or at 1022 the bottom. 
1023 Table 6: Variation explained by the fixed effects.

1024

\begin{tabular}{lcccc}
\hline Covariates $^{a}$ & Cod & Haddock & Whiting & Plaice \\
\hline Presence/Absence & $(\%)$ & $(\%)$ & $(\%)$ & $(\%)$ \\
Year Day & 16.1 & 33.2 & 25.7 & 1.3 \\
Bottom Depth & 3.1 & 27.2 & 10.8 & 8.6 \\
Temperature & - & 33.0 & 15.3 & 8.3 \\
Salinity and $\sigma_{\mathrm{t}} \mathrm{g}$ & 0.9 & 22.0 & 5.1 & - \\
\hline Total & 15.9 & 47.1 & 29.1 & 9.6 \\
\hline Egg density & & & & \\
Year Day & 1.7 & 7.0 & 1.7 & 4.4 \\
Bottom Depth & 2.1 & 17.4 & 4.5 & 2.9 \\
Temperature & 5.0 & 21.4 & 6.8 & 1.1 \\
Salinity and $\sigma_{\mathrm{t}} \mathrm{g}$ & - & 28.9 & 9.2 & 7.9 \\
\hline Total & & 30.5 & 9.9 & 13.2 \\
\hline & 5.0 & & & \\
\hline
\end{tabular}

1025

$102 a^{a}$ ) Variation partitioning only allows for four components. Therefore salinity and density

1027 gradient were, if necessary, grouped. Values for single covariates contain a pure

1028 component and a component shared with other covariates. Hence, the terms sum up higher

1029 than the total variation explained. $\sigma_{\mathrm{t}} \mathrm{g}=$ density gradient 
1030 Table 7: Log-likelihood ration test between GAMM and corresponding GAM models for 1031 presence/absence as well as density of eggs for the four species.

\begin{tabular}{|c|c|c|c|c|c|c|c|c|}
\hline \multirow[t]{2}{*}{ Species } & \multirow[t]{2}{*}{ Type } & \multicolumn{2}{|c|}{$\overline{A I C}$} & \multicolumn{2}{|c|}{ BIC } & \multicolumn{3}{|c|}{ Log-likelihood ratio test } \\
\hline & & GAMM & GAM & GAMM & GAM & $\chi_{0.05}^{2}$ & df & $\mathbf{p}$ \\
\hline \multirow[t]{2}{*}{ Cod } & Presence/Absence & 1938.8 & 1930.0 & 1957.0 & 1939.1 & 4.8 & 2 & 0.09 \\
\hline & Egg density & 1079.6 & 1076.2 & 1096.6 & 1084.7 & 0.6 & 2 & 0.75 \\
\hline \multirow[t]{2}{*}{ Haddock } & Presence/Absence & 1626.6 & 1613.4 & 1653.9 & 1622.5 & 5.2 & 4 & 0.26 \\
\hline & Egg density & 672.5 & 659.7 & 695.4 & 667.3 & 4.8 & 4 & 0.31 \\
\hline \multirow[t]{2}{*}{ Whiting } & Presence/Absence & 1921.2 & 1914.4 & 1934.8 & 1923.5 & 4.7 & 1 & 0.03 \\
\hline & Egg density & 1005.6 & 998.7 & 1017.9 & 1006.9 & 4.9 & 1 & 0.03 \\
\hline \multirow[t]{2}{*}{ Plaice } & Presence/Absence & 2046.1 & 2037.9 & 2073.3 & 2046.9 & 0.2 & 4 & 1.0 \\
\hline & Egg density & 584.8 & 574.2 & 608.1 & 582.0 & 2.6 & 4 & 0.6 \\
\hline
\end{tabular}


1033 Figure 1: Panel (a) shows the ichthyoplankton stations for 2004 and 2009 over a 1034 bathymetric map of the North Sea. Panel (b) exhibits the operational installations 1035 related to oil extraction; color-coded depending on the operating country on the 1036 same bathymetric map. Red lines depict Exclusive Economic Zones (EEZs). Areas

1037 shaded pink; show the areas with planned or ongoing seismic surveys in the 1038 Norwegian and Dutch sectors. Germany is not conducting seismic surveys and for 1039 the UK and Denmark no information is publicly available.

1040

1041 Figure 2: Mean Temperature and Salinity at the surface (5 m; panels (a, b) and at 1042 bottom depth (c, d), based on data from the first quarter of 2004 and 2009. Black 1043 dots indicate individual CTD hauls.

1044

1045 Figure 3: Range of structures of spatial autocorrelation (a) for the individual 1046 species. Broken lines indicate where the structures were grouped into the scales 1047 depicted, in the order fine to broad, on the maps on panels (b) to (e). The plotted 1048 structures are those for haddock, except on medium-broad scale (d) where there 1049 was only a single structure, for cod.

1050

1051 Figure 4: Mean interpolated surfaces for the distribution of eggs in each stage, 1052 drawing from both surveys. Interpolated areas beyond $200 \mathrm{~m}$ bottom depth are 1053 blanked out. Black dots on panel (a) indicate the sampling stations for both years. 1054 
1055 Figure 5: Predicted probability of occurrence for stage I eggs of all four species, on 1056 the range of the covariates in the best fitting models. Broken lines indicate models 1057 using hydrographic values measured at the surface. Hatches at the bottom of each 1058 panel indicate the values observed at samples. As cod was related to surface salinity, 1059 while haddock was related to bottom salinity on a narrower range, the 1060 corresponding observations are depicted in colours corresponding to the smooth 1061 terms. Shaded areas indicate the 95\% confidence interval. 1062

1063 Figure 6: Predicted log-transformed stage I egg density for stage I eggs of all four 1064 species, related to the covariates in the best fitting models. Broken lines indicate 1065 models using hydrographic values measured at the surface. Observations with non1066 zero egg densities for the individual species are indicated by hatches, in the same 1067 colour as the smooth term, at the bottom of each panel. Shaded areas indicate the $106895 \%$ confidence interval.

1069

1070 Figure 7: Panel (a) shows the average stage I egg density for each ICES rectangle on 1071 the interpolated surface of bottom temperature variability, based on CTD data for 1072 the $1^{\text {st }}$ quarter of the entire 2000s. Panel (b) depicts installations of the oil industry, 1073 categorized as above-surface (red dots) or subsurface structures (white squares) 1074 the position of oil industry installation and the seismic survey areas for Norway and 1075 the Netherlands, shaded blue, on top of the average distribution of stage I eggs for 1076 all four species combined. 


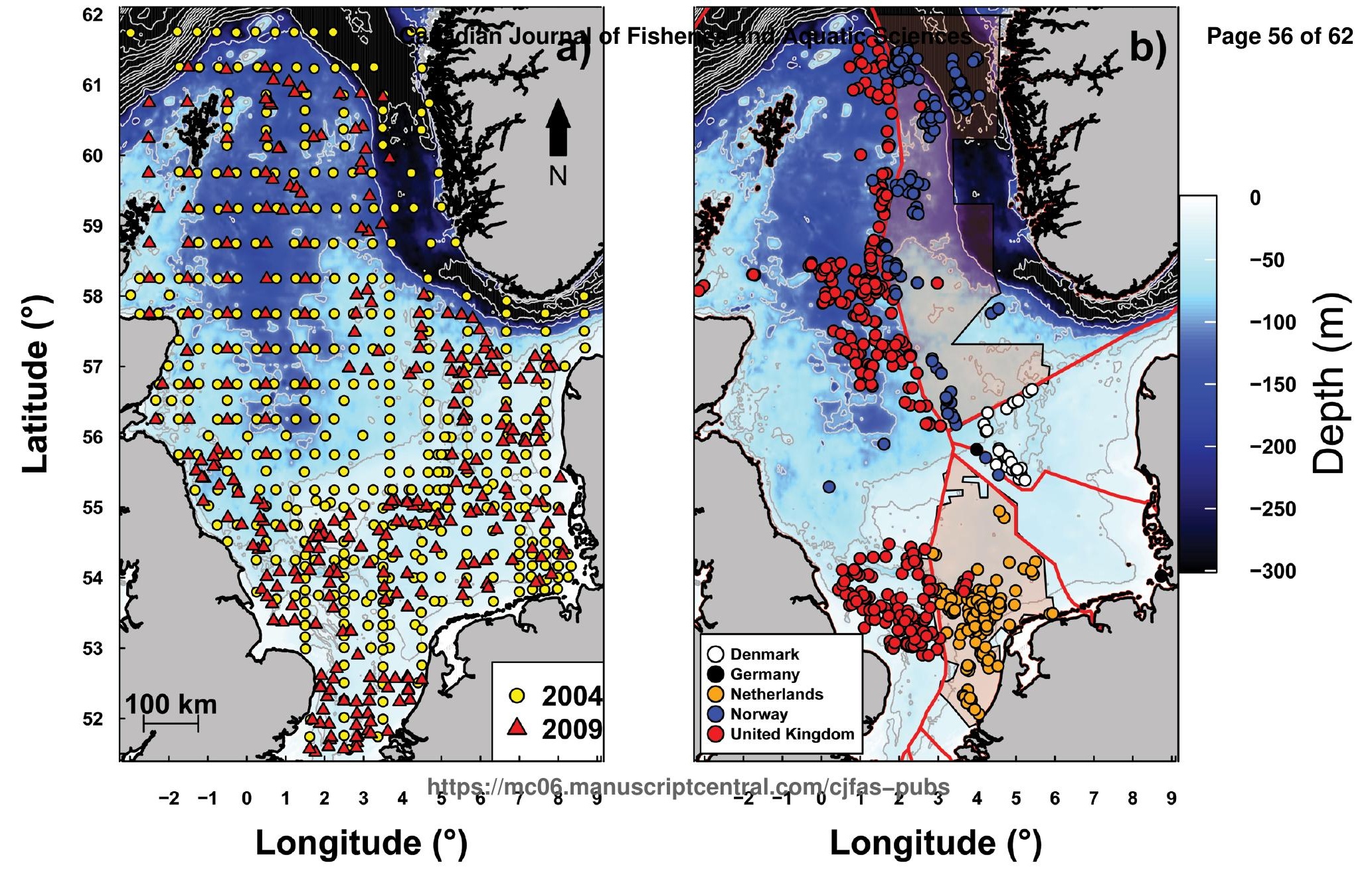



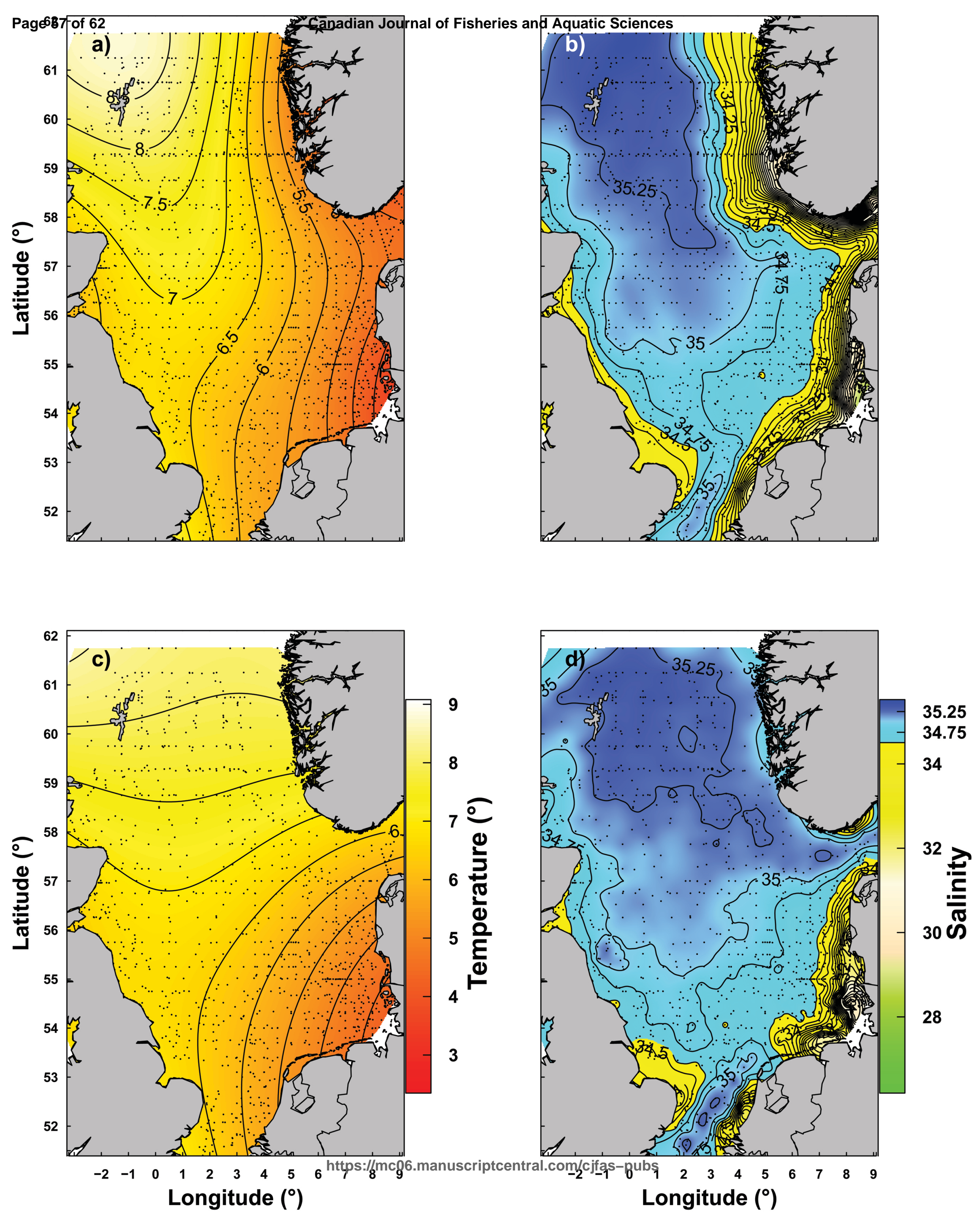

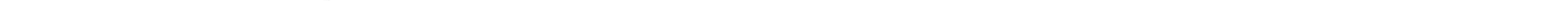


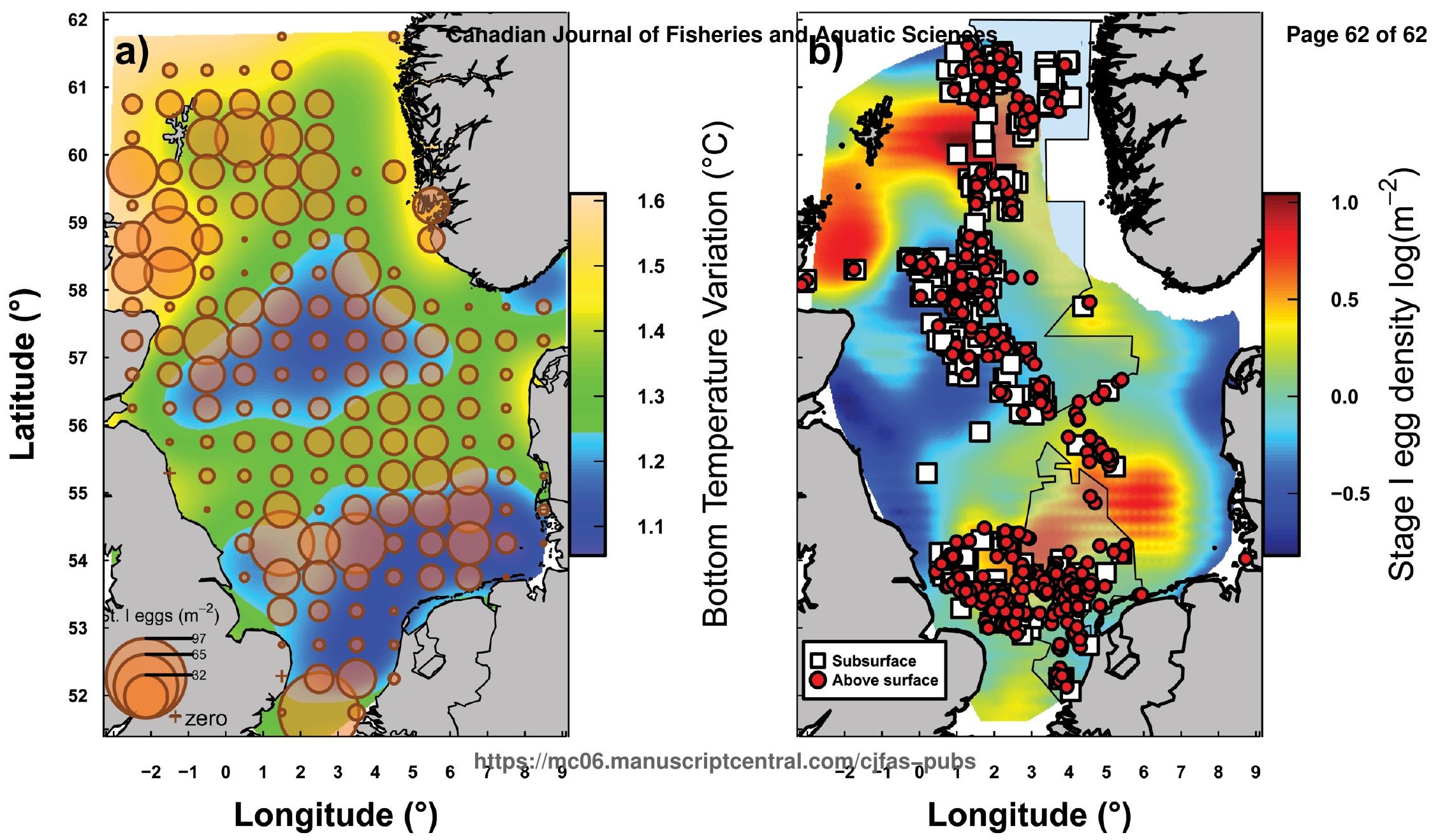

